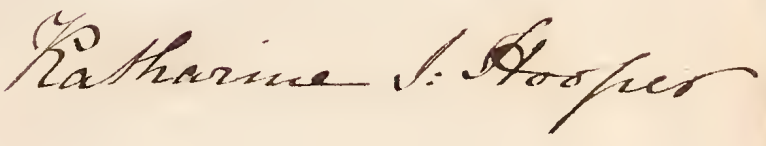




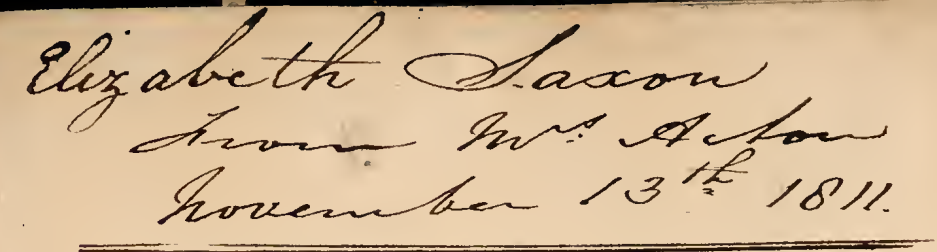

FIFTY PLATES

oF

\section{GREEN-HOUSE PLANTS,}

DRAWN AND COLOURED FROM NATURE.

WITH

CONCISE DESCRIPTIONS, AND RULES FOR THEIR CULTURE.

INTENDED ALSO

FOR THE IMPROVEMENT OF YOUNG LADIES IN THE ART OF DRAWING.

BY

HENRIETTA MARIA MORIARTY.

Second EEDition.

\section{LONDON:}

PRINTED FOR THE AUTHOR,

By T. Bensley, Bolt Court,

AND SOLD BY J. WHITE, FLEET STREET.

1807. 


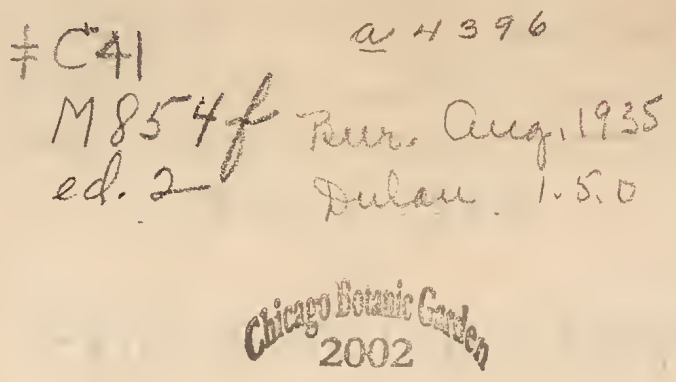

The Bowager Lady de CLIFFORD.

Madam,

I AM well aware that flattery is a sort of incence, which your ladyship is not disposed to receive, and, if I know any thing of my own heart, it is that, with which I am not inclined to offend you.

The sanction of a name, so deservedly approved as your's, naturally gives me the flattering hope, that the time which I spent in executing this work, was not cmployed uselessly. 
Suffer me then, as a testimony of high respect for your ladyship's character, and of gratitude for kindness to me and $m y$ children, to subscribe myself,

\section{Your Ladyship's}

Most obliged, most faithful,

And humble servant,

H. M. Moriáttr.

BOLEY-MILL, RochestrR, JAN, 1306. 
ings in public boarding-schools: the senses cannot be too soon habituated to the nicer discrimination of objects : and those who have the instruction, or, I might say, the formation, and even the fashioning of young minds most at heart, often find it difficult to obtain representations in this most pleasing branch of natural history; on the one hand sufficiently accurate, and, on the other, entirely free from those ingenious speculations and allusions, which, however suited to the physiologist, are dangerous to the young and ignorant: for this reason I have taken as little notice as possible of the system of the immortal Linneus, and of all the illustrations and comments on it: nay, I have not once named the fanciful Doctor Darwin, and, having no desire to extenuate the merit of any writer, or to sipercede the use of his labour, it will be pleasure and satisfaction enough for me if my own performance shall prove such an one as the rising generation can consult with safety and advantage.

Another object which, I flatter myself, I have in view, without presumption, is, that I may sometimes lay the foundation of a taste for the most refined pleasure that the ficld or garden can afford, and, at the same time, instil an early conviction of the wisdom in which are made the manifold works of the Supreme Being. 
Much more I might add; but, if I pioceed, I foresce that I shall not casily know when to end; therefore, having premised so much, I conclude by deprecating the sererity of censure, and by trusting to the favour of my reader.

\section{LIST OF THE SUBSCRIBERS.}

His Royal Highness the Duke of Sussex, 2 eopies

Abernathie, Capt.R.M.A. Boys, Mrs.

Aneram, Mrs. Bramstone, Mrs.

Anspach, Margravine of Briggs, John, Esq.

Arden, Lady

Arden, Lord

Broke, I.oId Willough-

Aubin, Mrs.

Browne, Capt.Alex.R.M.

Bailly, Mr.

Baker, Mrs.

Browne, Lieutenant Ad-

Baker, Miss C.

jutant, R. M.

Ballingall, Col. r. м. Campell, Gen. J. R. M.

Barelay, General R. M. Cassell, Major, R. M. 2 eopies

Barrington, Hon. Mrs.

Battin, Joseph, Esq.

Battin, Mrs.

Beaufoy, Mrs.

Bell, Mrs. Riehard

Berkeley, Col. R. M.

Biggs, Miss.

Blancowe, Mrs.

Boghurst, John, Esq.

Bolton, Lady

Bourmaster, Mrs.

Boys, Capt. R. M.

Cavanagh, Lieut, R. M.

Chadwick, James, Esq.

Chester, Mrs.

Chester, Hon Miss

Clarges, Sir 'T. 2 copies

Clifford, Lady de, 5 eopies

Coates, Miss 5 eopies

Coates, Miss for a friend

Colly, Lieut. Adj. R. M.

Collins, John, Esq.

Colborne, N. R. Esq.

Colpoys, Sir J, 5 copies Cos, Miss 
Cox, Capt. R. M. Garnier, Mrs.

Creswell, licut. Garrett, Mrs.

Gordon, Capt. R. M.

Greeme, Charles, Iisq.

Grape, Iieut. R. M.

Damn, Wiluam, Esq

Davids, Bishop of St.

Jixon, Mrs. 1 .

Doorn, Est

Grey, IIon. Commissr.

Grey, Mrs. 3 copies

Douglas, Doctor

Doughas, Mis.

D'Oyly, Rev. Mr

D'Oili, Colonel

Grimstone, Henry, Esq.

Grosvenor, luady

Guitlon, Mrs.

D)Oyly, Capt.1I.1st Reg

$$
\text { Guards }
$$

Gurney, Mrs.

Hall, T. Esq.

Drumriond, A. B. Esq. Hamilton, Lady

Drummond, Lady Mary Hemmings, Miss

Drommond, C. Est. Hervey, Mrs.

Drummond, Mrs. C. Hill, Col. R. M.

Drummend, John, Fsq. Hill, Lieut. R. M.

1)rummond, Mrs. Hoare, Charles, Esf

Dymock, Cast. R. M. Jorkins, Mrs.

Horgood, Miss

Horeood, Miss

Therington. Colonel

Gitre, Iady

Eyre, Mrs.

5 copies

Fijeld, Lady Hulks, James, Esq. M.P.

Jervoise, Mrs.

Jervoise, Mrs. G.

Fielding, Mrs. Isabella Innes, Mrs.

foreman, R. Esq.

Frith, Mrs. .

Fritl, Miss

Fuller, Mrs. Gicorge

Gardiner, I ady

Jones, Lieut. 2 M. R. M.

Kcrwin, Miss

Lascelles, Mrs.

Law, Rev. Dr.

Garnier, Lady Eliz.

Leighton, Col.T. 2 copies
Leighton, Mrs. Forrester Purvis, Mrs. G.

Liston, Mrs.

Loekwood, Miss

Loveden, Mrs:

Lyells, the two Miss

Maitland, Mrs.

Manners, Miss

Marsham, Hon. Rev.Dr.

Minto, Capt. R. M.

Moore, Rev. Charles

Moore, Rev. Thomas

Moore, Lieut. R. M.

Mount, Mrs

Muller, C. F. Esq.

Purvis, Mrs. 1.

Musgrave, George, Esq.

Nesbit, W. H. Esq.

Nixon, John, Esq.

Northampton, Countess

Obrien, Captain, R. M.

Orton, Captain, R. M.

Parker, Iicut. R. M

Pawlet, Gen.

Pinfold, Esc.

Penneman, Miss Vliza

Perceval, Lady Eliz.

P'ole, Hon. Mrs.

Porter, Gen. M. P.

Porter, Mls. 2 copics

Purvis, C. Esq. 1 cones Taughan. Dondw:

Purvis, George, lisq.

Radeliffe, Mrs. R.

Reeves, Mrs.

Rieh, Miss

Ridesdale, Lady

Ridley, Lady Guards.

Rous, Lady

Rowley, Mr.

Seott, Hon. Mrs.

Smith, Mrs.

Sutton, Miss

Tench Colonel,

Teny, Miss Mars

I'owers, Esq.

Tryar, Doctor

Tubls, Mrs. li.

Inopemy, Mr:
Radcliffe, Rev. Doctor

Ridley, Sir M.W. M. r.

Ridley, Mat. W. Esq.

Rigg, Capt. 1st Reg. of

Roehester, Dean of

Rowe, Capt. R. M.

Seward, Capt R. M.

Smith, Mrs. Samucl

Smith, Capt. R. M. 
Walpole, Lady M. Watson, Miss Julia Ward, Mrs. Weldon, Mrs.

Ward, Mrs. E Wells, Miss

Ward, Miss

Warren, Mrs

Williams Capt. R. M.A.

Wools, Mrs. 


\section{LILY.}

Lat: Agapanthus Umbellatus.

Cl: HEXANDRIA.

Ord: MONOGYNIA.

There are two varieties of this plant, a Ma jor and a Minor.

Plant the roots in light earth from offsets, when the leaves and stalks decay.

They flower in the autumn, and continue a long time in blossom.

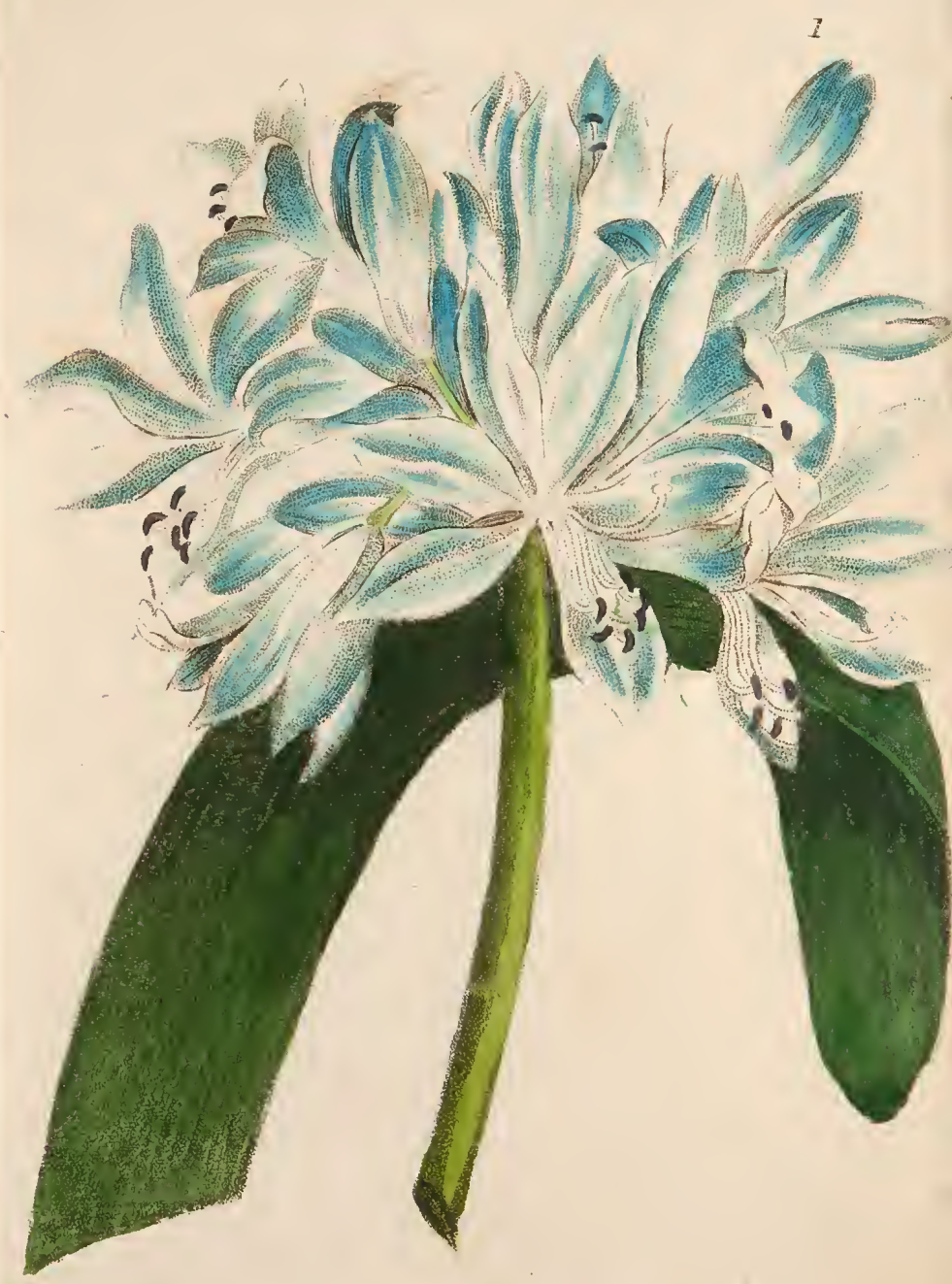

Agnpanthus, or Bhue Lity. 


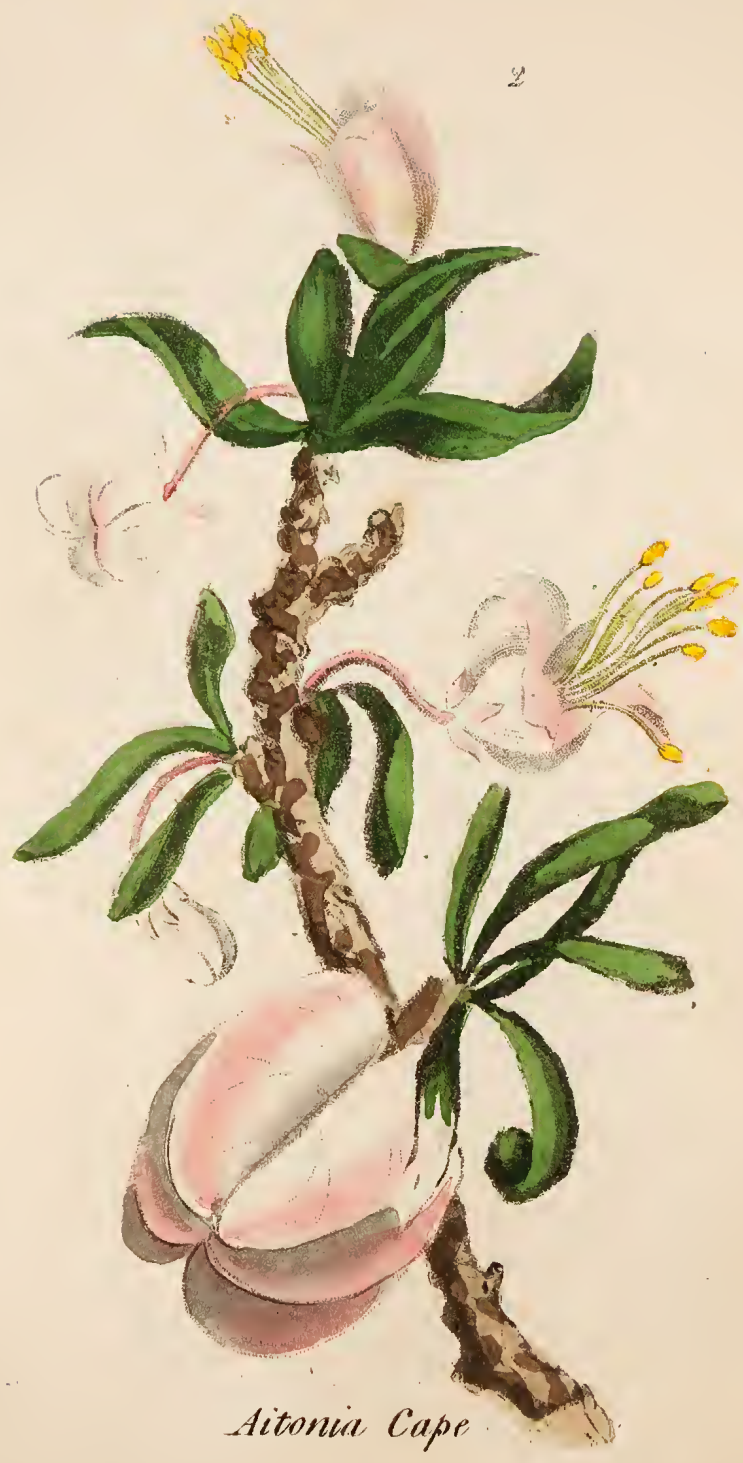

CAPE AITONIA.

Lat: Aitonia Capensis,

Cl: MONODELPHIA.

Ord: OCTANDRIA.

This is a shrub of slow growth, which produces its blossoms and fruit great part of the year.

The fruit is a red berry.

It is propagated by seeds. 
Lat: Aloë Variegata.

Cl: HEXANDRIA.

Ord: MONOGYN IA.

The plant from which this drawing was taken, was two feet high, but in general it seldom exceeds eighteen inches.

It continues in blossom all the summer, and its foliage is extremely beautiful.

It is increased by offsets, suckers, or by cutting the leaves, which should lay some days to dry previous to their being planted.

This plant requires light earth, and the rooting is greatly facilitated by being placed in 2 Hot-bed.

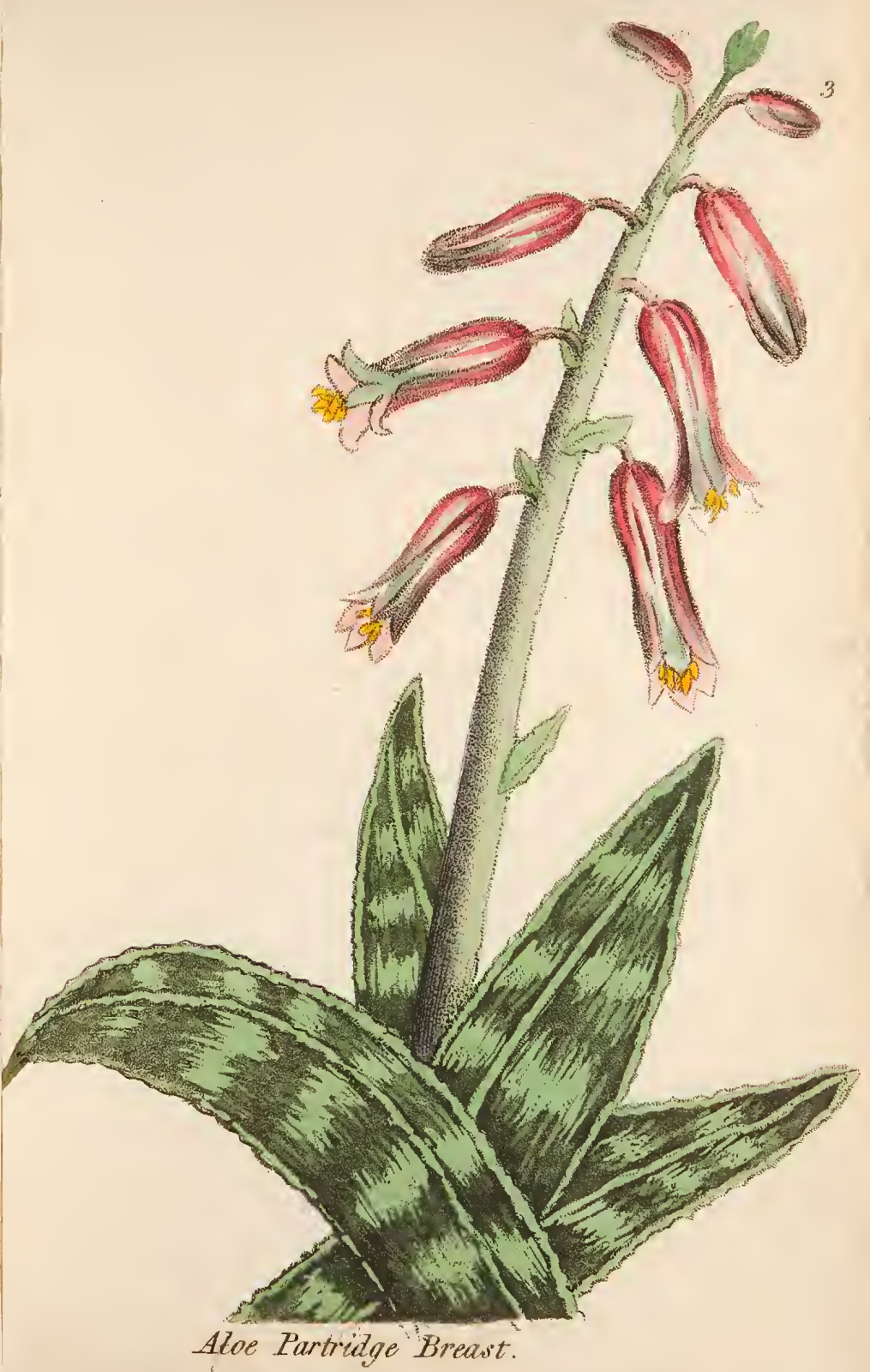




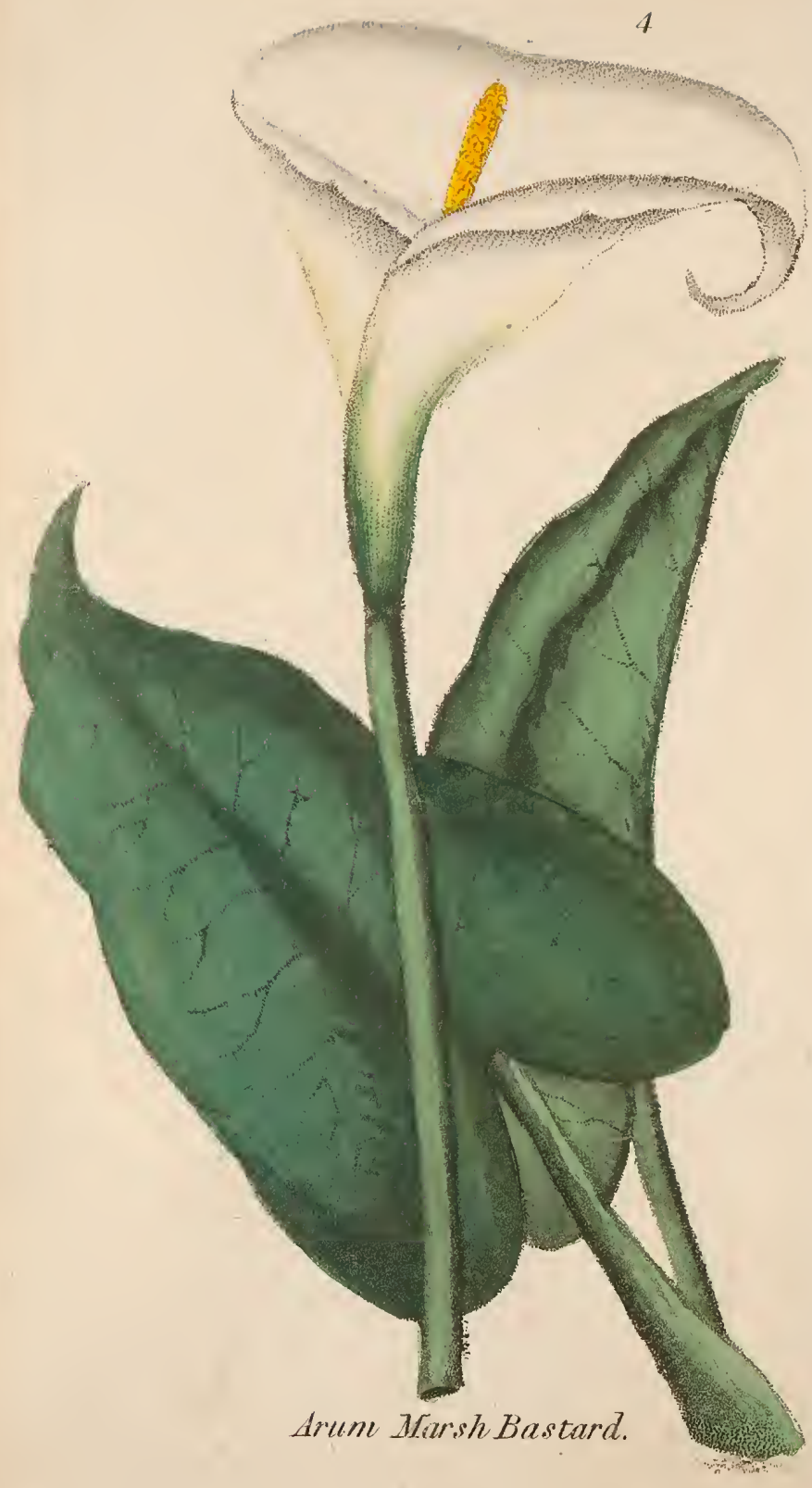

MARSH BASTARD ARUM.

Lat: Calla Palustris.

\section{CI : GYNA NDRIA.}

Ord： POLYANDRIA.

This drawing was taken from a plant nearly three feet higl, it blossoms in March, and continues in leaf all the year.

It is propagated by offsets, which should be planted singly, and in light earth. 
EGYPTIAN BIND-WEED.

\section{Lat: Convolvulus Cairicus.}

Cl: PENTANDRIA.

Ord: MONOGY IA.

Althongh this beautiful plant is called the Egyptian Bind-weed, yet its native place is not known.

It is encreased by cuttings, and requires light eartl.

Seeds sown in a IIot-bed, will succeed.

It flowers in June, July, and August.

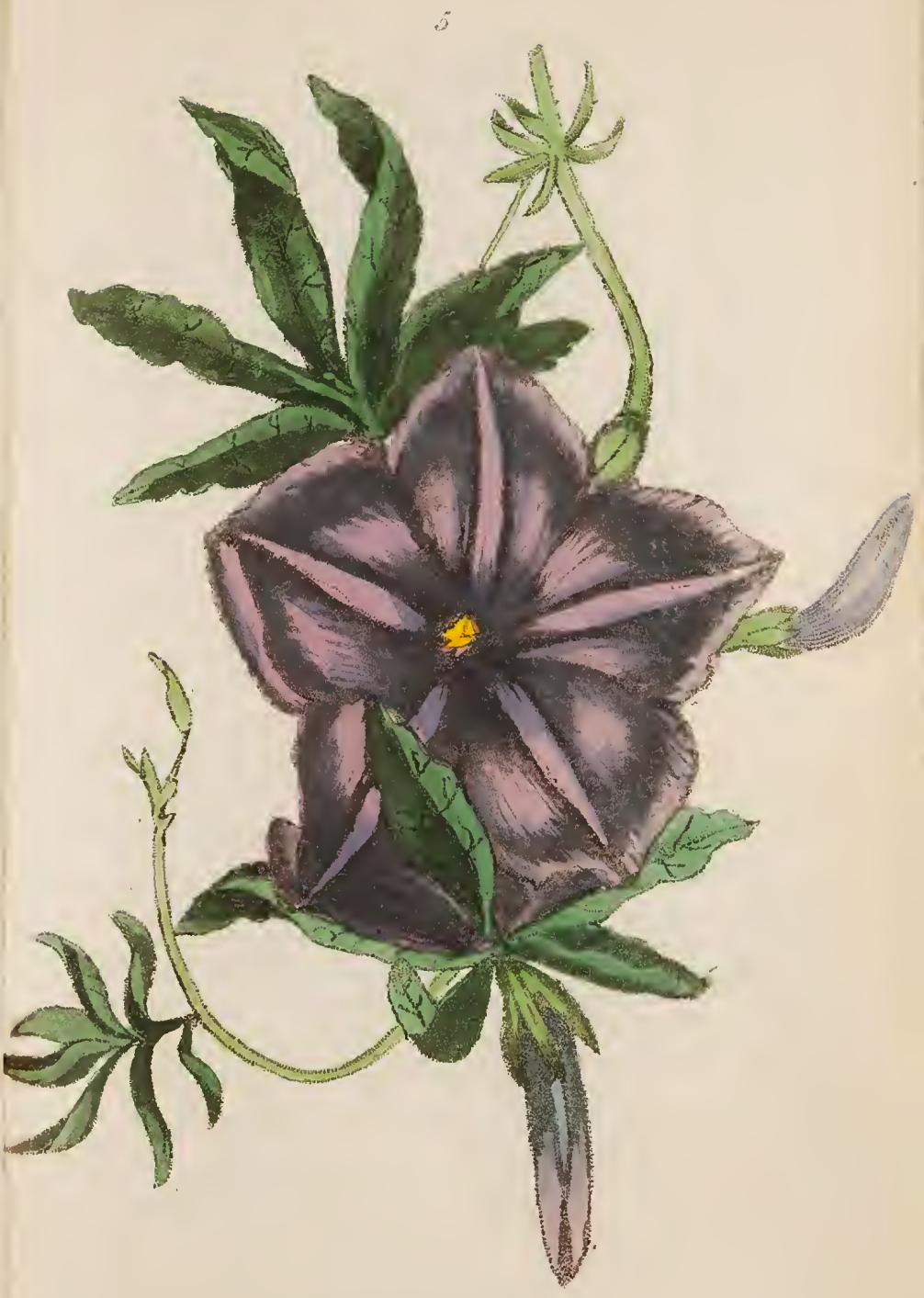

Bind Werd-Egyprinn. 


\section{6}

\section{ROUND-HEADED BUDDLEA.}

\section{Lat: Buddlea Globosa.}

\section{Cl: TETRAN D RIA.}

Ord: MONOGY IA.

The Buddlea is a beautiful plant, which grows to a great size, it is considered as belonging to the Green-house, but it will succeed in the open border, if care is taken to shelter it from the Frost.

It is easily propagated by either cuttings or layers; it blossoms in May and June. 
SCARLET-BLADDER SENNA.

Lat: Colutea Frutescens.

Cl: D I A D L PHIA.

Ord: DECA N D R IA.

This ornamental shrub flowers in July. Occasionally it is placed in the shrubbery; but, as it requires a warm situation in the winter (as frost destroys it), it is generally considered as belonging to the Green-house, where it grows to two or three feet in height. 


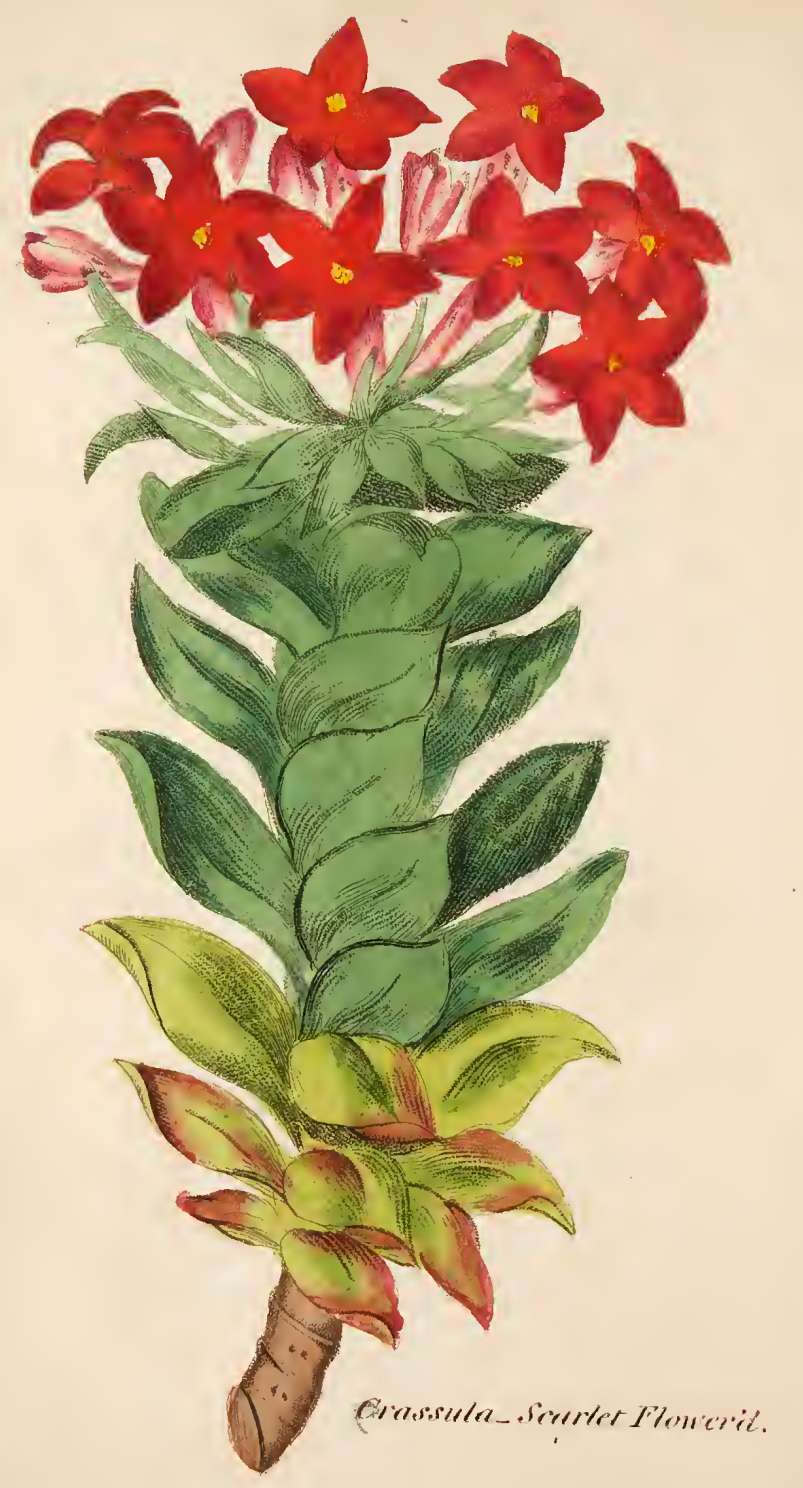

\section{SCARLET-FLOWERED CRASSULA.}

\section{Lat: Crassula Coccinea.}

\section{CI: PENTANDRIA.}

Ord: PENTAGYNIA.

The richness of the colour, and the superb appearance of this plant, make it much esteemed in a Green-house collection.

It generally flowers in June, July, and August, also, sometimes, in the spring.

It is propagated by cuttings of the stalks and branches; it succeeds best in a sandy compost; it should be very seldom watered in the winter, and about twice a week in the summer.

This plant requires being sheltered from the sun, 
DARK-COLOURED CATCHFLY.

Lat: Silene Ornata.

\section{Cl: DECANDRIA.}

Ord: TRIGYN IA.

The richness of the colour of this plant se cures it a place in every Green-house.

It came from the Cape; it begins to blossom in June, and is easily propagated either by sceds or by cuttings.

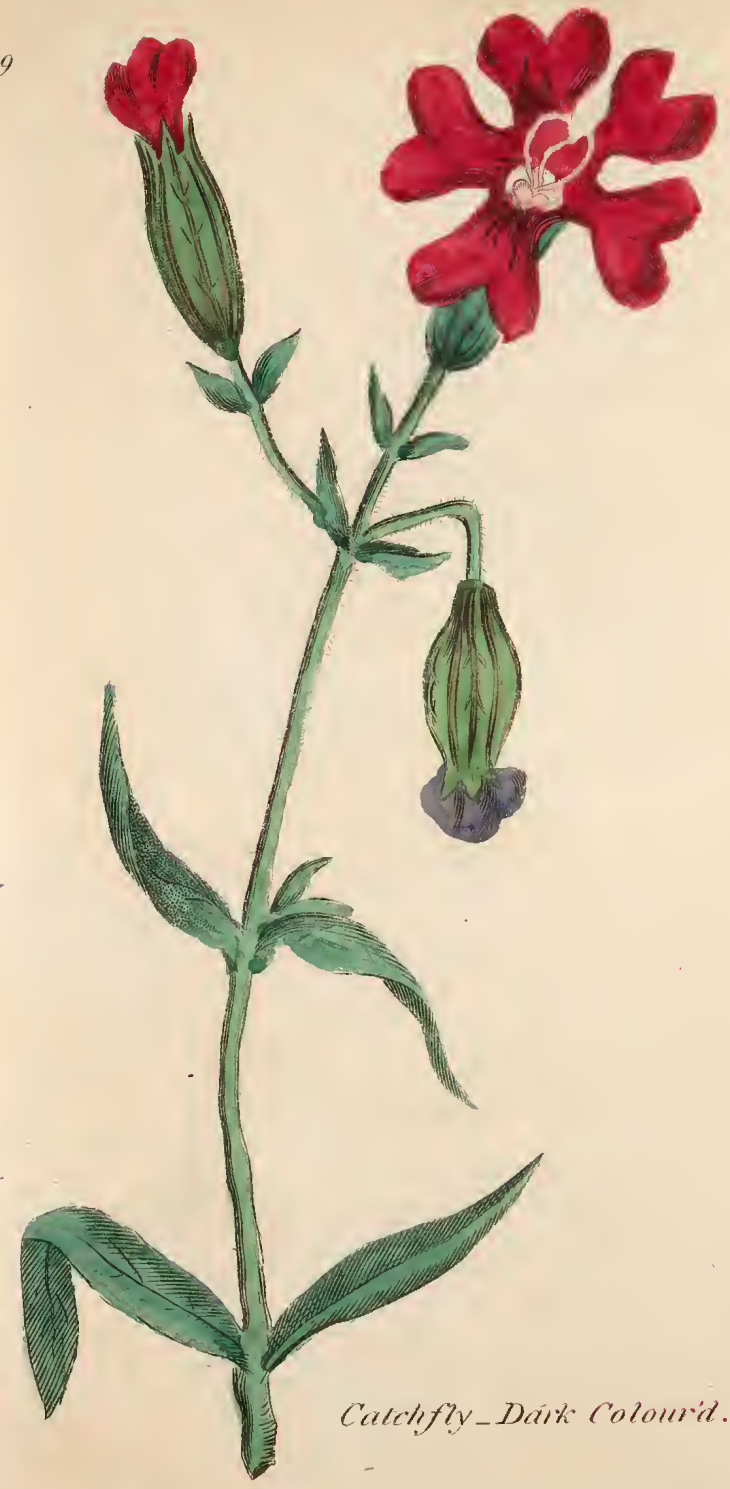




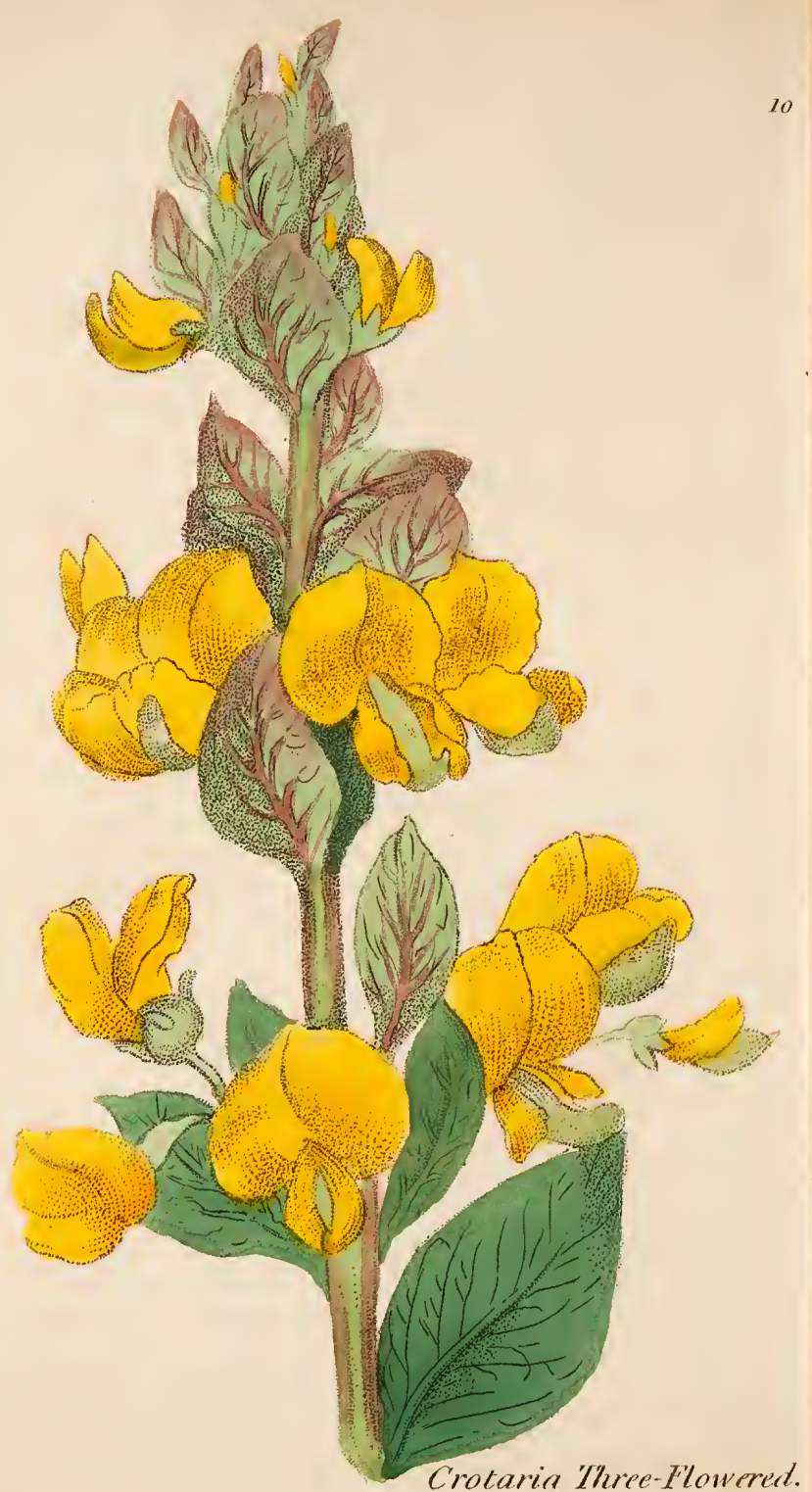

THREE-FLOWERED CROTALARIA.

Lat: Crotalaria Triflora.

Cl: DIA DELPHIA.

Ord: DECA NDR IA.

This plant makes a beautiful appearance, producing large yellow bunches of flowers, in June and July; it rises to the lieight of three or four feet.

It is propagated by cuttings, and also by seeds; the assistance of a Hot-bed will be found necessary for either. 
CREEPING CEREUS.

Lat: Caetus Flagelliformis.

\section{$\mathrm{Cl}: \mathrm{ICOSANDRIA}$}

Oril: MONOGYNIA.

Is a native of America, where it grows wild among the rocks; formerly it was considered as a Stove plant, but experience has proved, that it is sufficiently hardy to thrive in the Greenhouse.

It is propagated by cuttings of from three to six inches, taken off in joints from the branches: they should be laid in a dry place to heal the cut part, and may then be planted in pots with light soil; and to facilitate their rooting, theymay be put into a gentle I ot-bed, and then placed with the other Green-house plants.

The proper time for doing this is in the montlı of July.

This plant requires very litle water, and a dry situation in the summer.

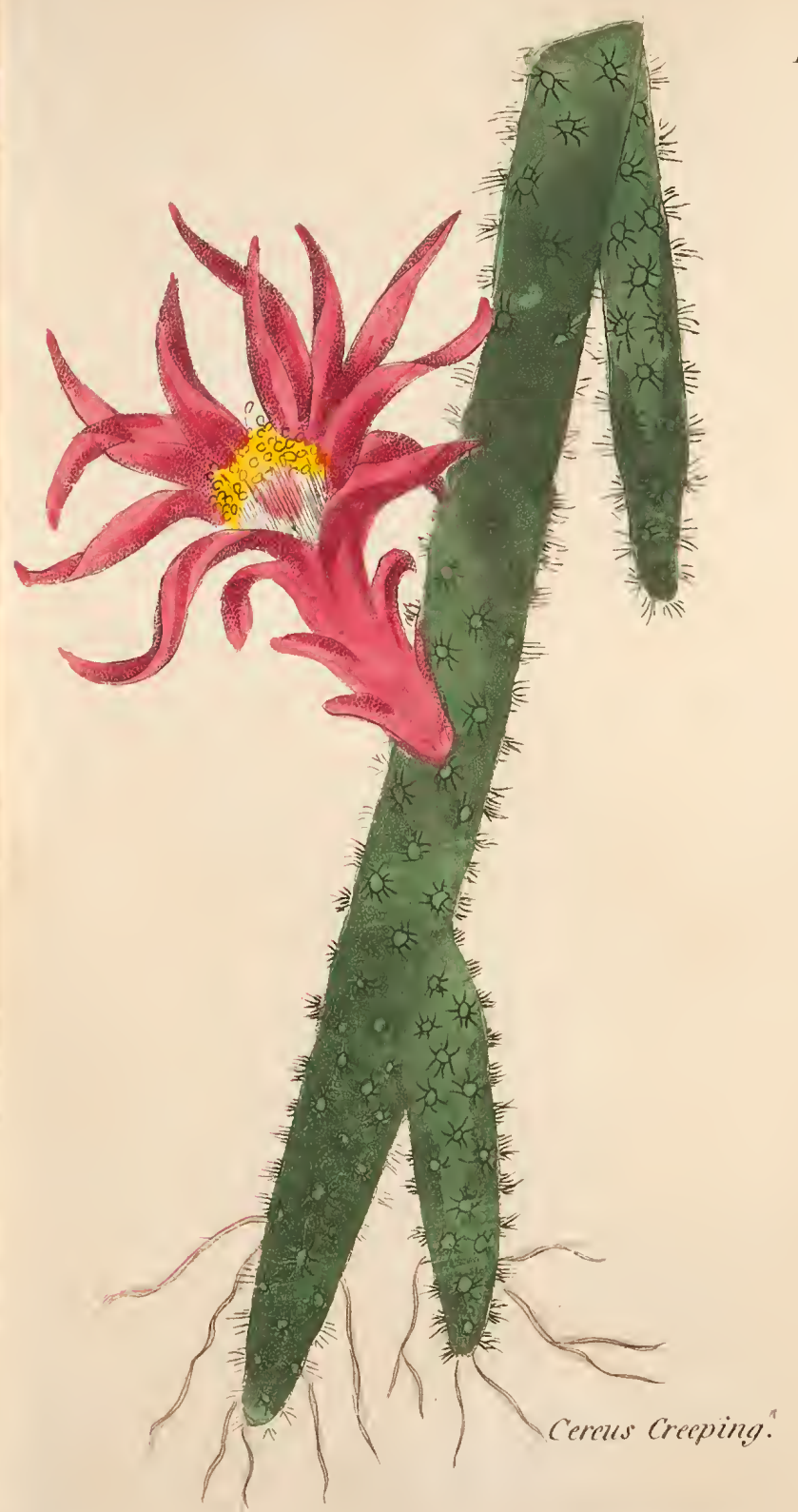




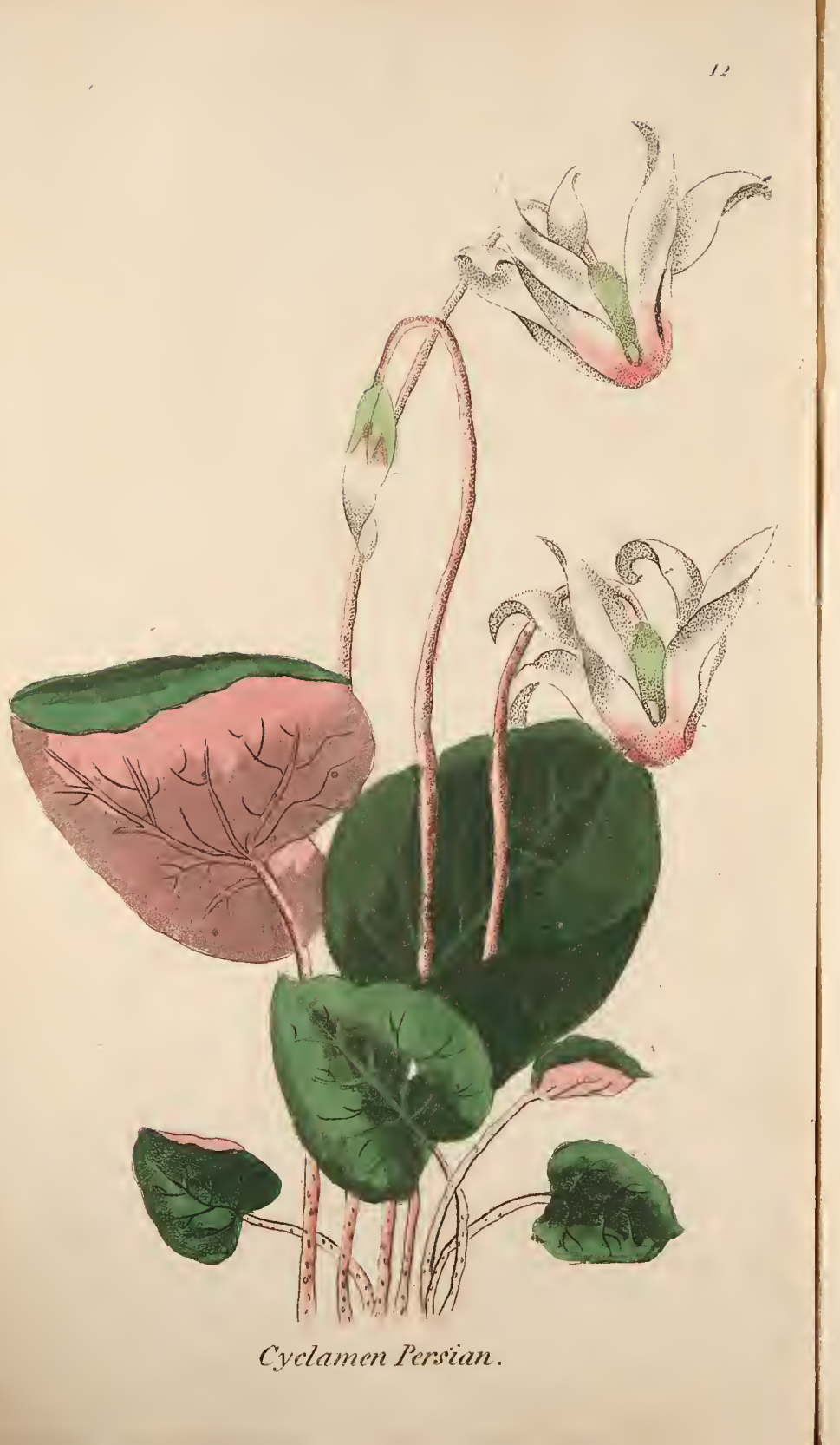

CYCLAMEN PERSIAN.

Lat: Cyclamen Persicum.

\section{Cl：PENTANDRIA.}

Ord: MONOGYNIA.

This elegant Cyclamen being a tender plant should remain in the Green-house.

It flowers early in the spring; may be propagated by seeds, or by parting the roots.

Plant them when the leares decay in light earth; they require very little water. 
SEA-GREEN，OR DAY-SMELLING CORONILLA.

\section{Lat: Coronilla Glauca.}

C!: DIA D ELPHIA.

Ord: DECA N D R I A.

This slirub furnishes a distinguishing variety in its ever-green leaves, and flowers all the year in the Green-house.

The blossom is fragrant in the day, but at night has no scent.

It is propargated by seed, which should be sown in pots, in March or April, and then placed in a moderate Hot-bed.

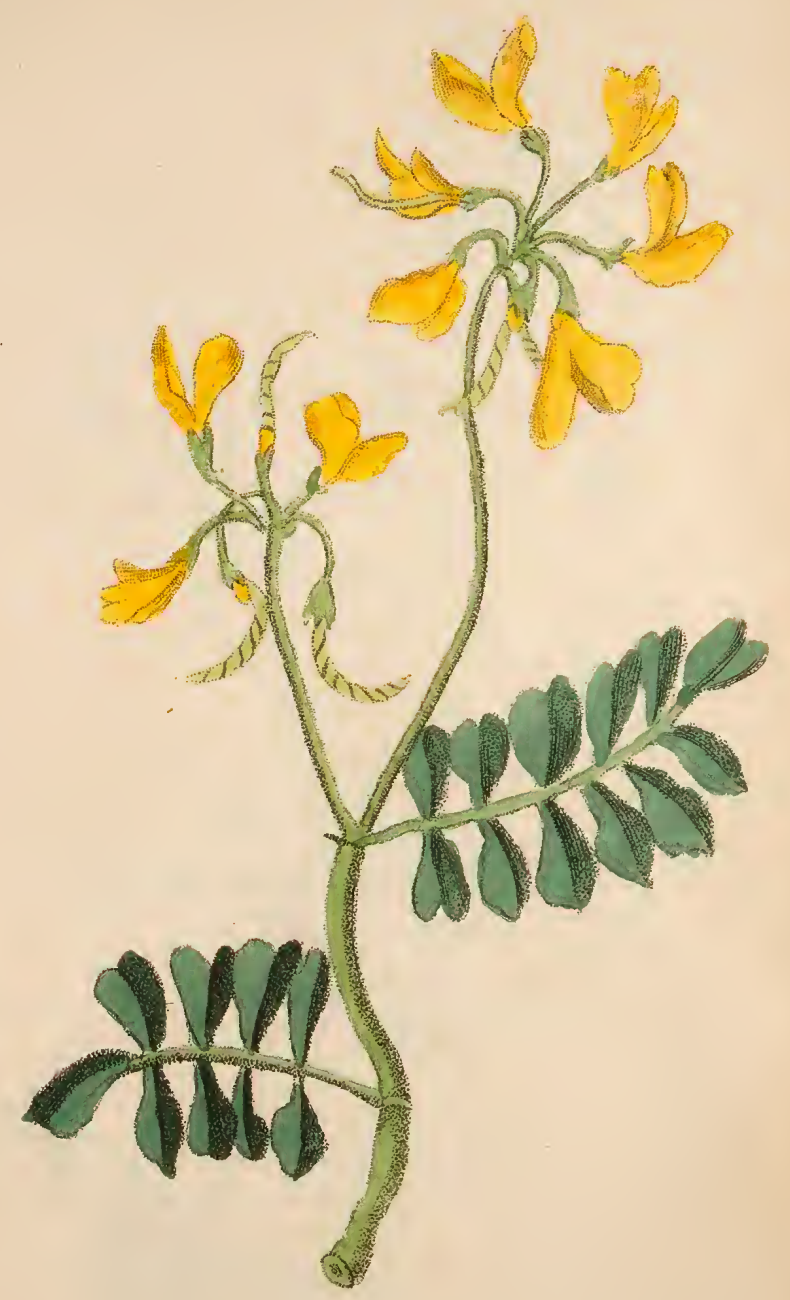

Coronilla Day - Smelima. 
Lat: Convolvulus Althacoides.

Cl：PENTANDRIA.

Ord: MONOGYNIA.

This elegant twining creeper deserves admittance into every collection, from its beautiful downy and silvery foliage.

It is propagated by layers and cuttings of the young shoots, and likewise by seeds raised in a Hot-bed.

It flowers in June, July, and August.

Convolvolus silky leaved.

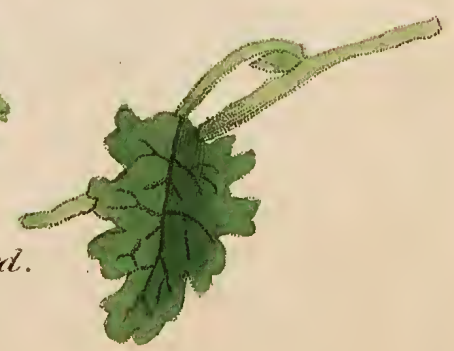




\section{Lat: Chironia Decussata.}

\section{Cl : PEN'TA N D R IA.}

Ord: MONOGYNIA.

This plant is very ornamental to a Greenhouse collection, as it flowers from June till October.

Sometimes it is propagated by cuttings, but it succeeds better by seed sown in pots of light compost, and placed in a gentle Hot-bed.

This should be done in the spring. 
THE CAPER-SHRUB.

Lat: Capparis Spinosa.

Cl: POLYANDRIA.

Ord: MONOGYNIA.

Capparis Spinosa is a native of Italy; the buds are the capers which we so mulch esteem in sauce.

Sometimes it is propagated by slit-laying the young branches, but it succeeds best from seed, which should be placed in a hot-bed.

This plant thrives most luxuriantly in an horizontal position, but it seldom arrives at perfection in this country. 
17

ROSE CAMELLIA.

Lat: Camellia Japonica.

Cl: MONADELPHIA.

Ord: POLYANDRIA.

Representations of this very beautiful Tree are frequently seen in Chinese paintings.

It is a native of Japan, where it grows to a great lieight, and bears single and double blossoms of various colours. It continues in flower from April to December, and succeeds very well in the Green-liouse.

It is propagated by cuttings.

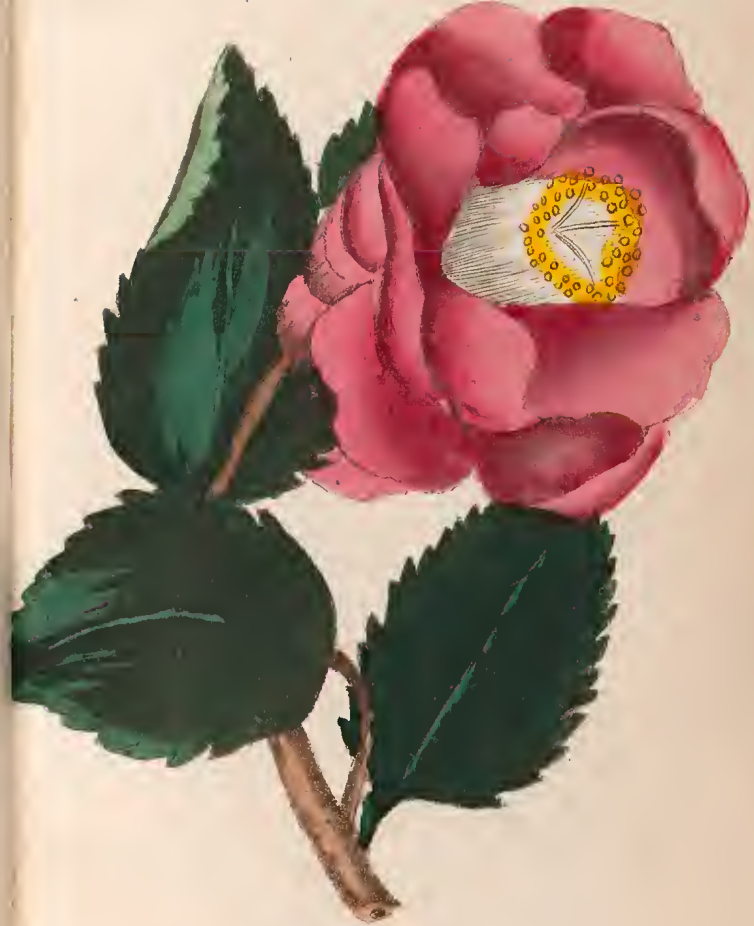

Camellin Rose. 


\section{8}

SNOW-WHITE CORN-FLAG.

Lat: Gladiolus Blandus. (var. B.)

\section{Cl: TRIAN DRIA.}

Ord: MONOGYNIA.

Plants of this species flower in May and June, and are propagated by offsets taken from the root, when the leaves decay; and also by seed.

They require light earth, and to be well sheltered during the winter. 
19

INDIAN CHYSANTHEMUM.

Lat: Chrysanthemum Indicum.

$\mathrm{Cl}:$ S Y N GE N ESIA.

Ord: POLYGAMIA SUPERFLUA.

The magnificent appearance of this plant, makes it to be held in such estimation by the Chinese, that they decorate their hair, and on particular occasions, ornament their tables with the flowers, which they consider as paying great liomage to their company.

It blossoms late in the year, and is propagated by parting the roots, or by slips: this may be done from March 'till Midsummer.

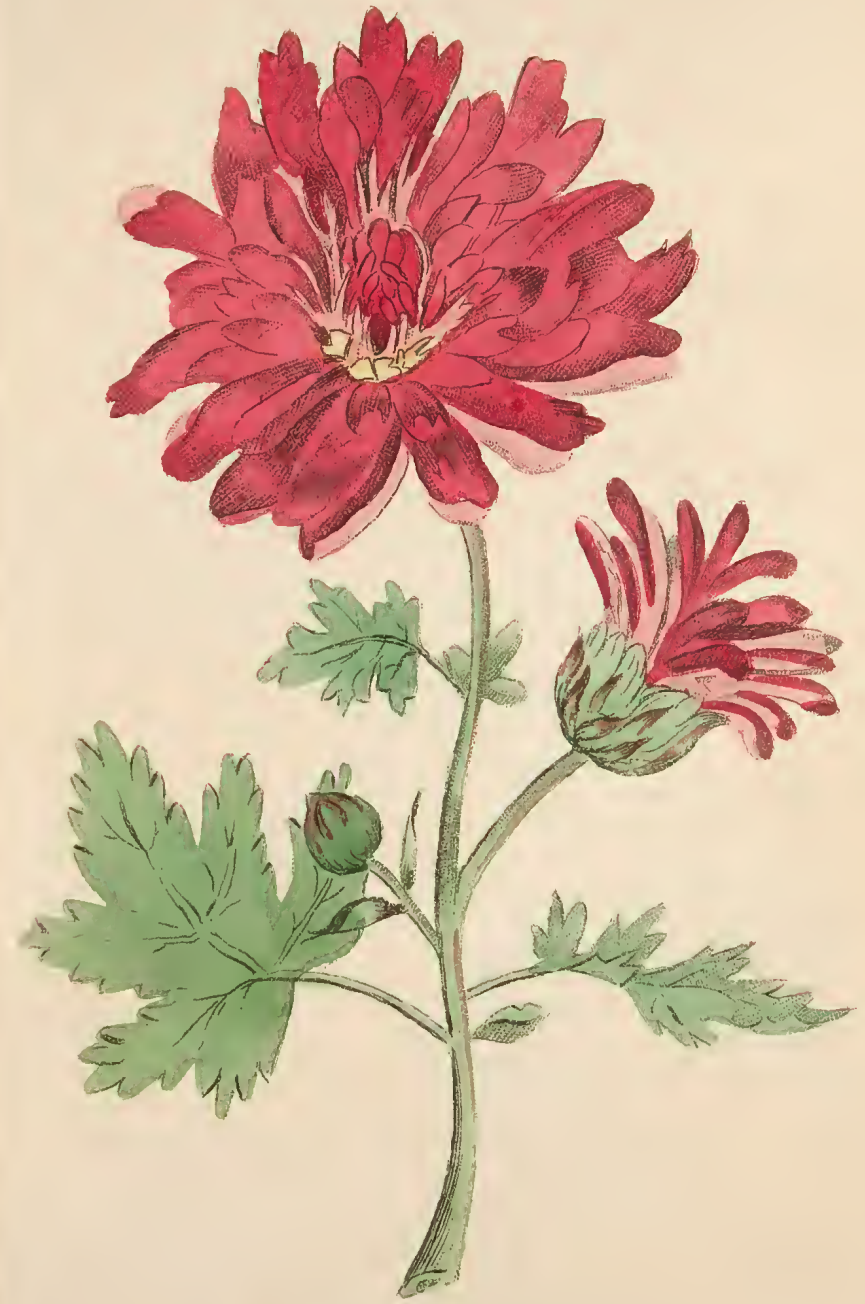

Chrivanthemusn Indinn. 


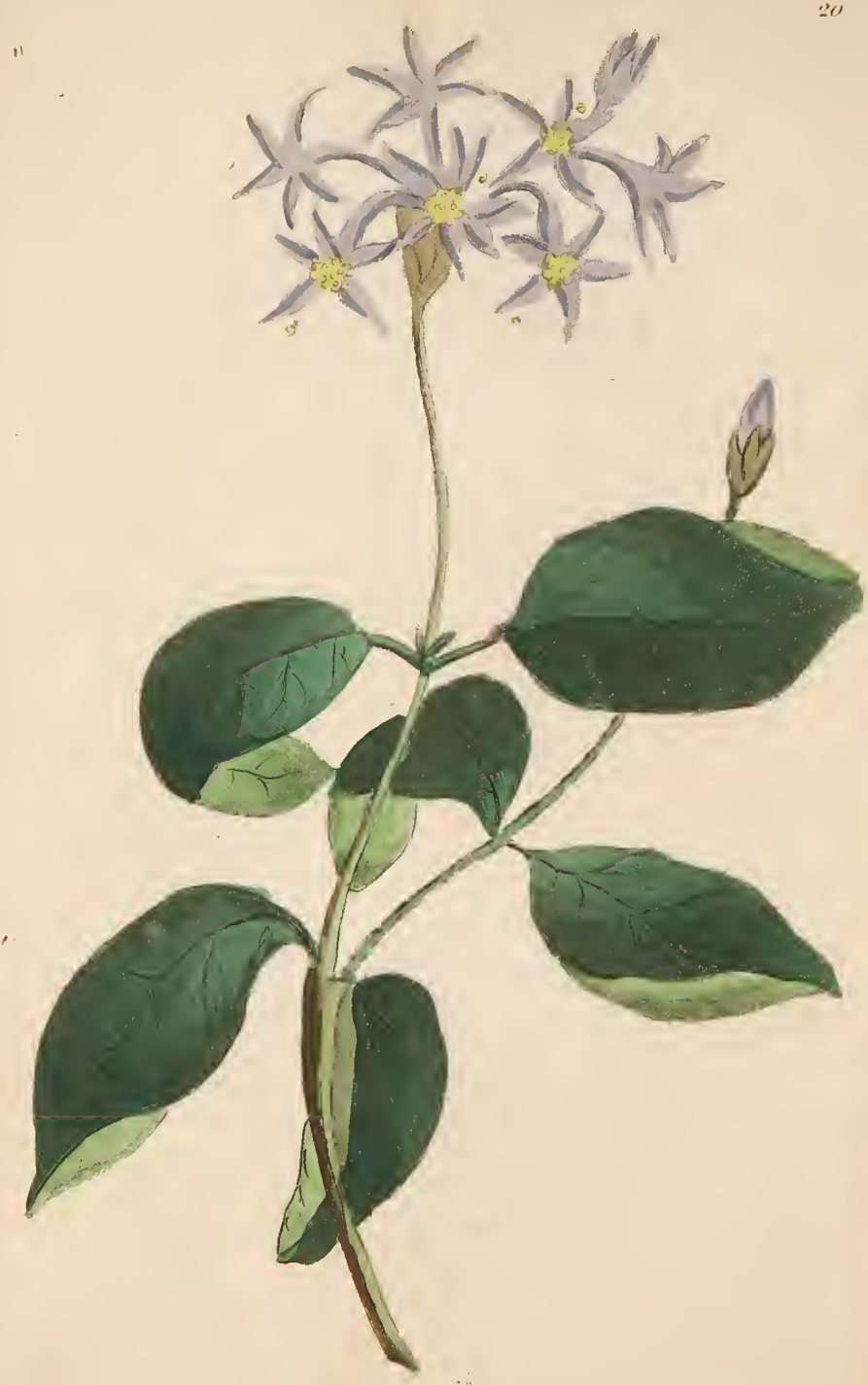

COTINUS-LEAVED DAIS.

\section{Lat: Dais Cotinifolia.}

Cl: DECA N D R I A.

Ord: MONOGY NIA.

This deciduous shrub, brought from the Cape, is very seldom to be met with here, because the right mode of propagating it is, perhaps, not yet ascertained.

It flowers in June and July.

Whether it has yet produced perfect seed in this country, I am uncertain : it had producef none in Mr. Curtis's time.

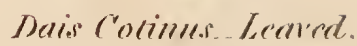


SCARLET FUCIISIA.

Lat: Fuchsia Coccinea.

Cl: O C T A N D R I A.

Ord: MO N OGYNIA.

This very favourite plant, from the beauty of the flower and foliage, justly claims a place in every Green-house.

It is propagated by layers, cuttings, and sceds, and although it is properly a Green-house plant, yet it is of so liardy a nature as to grow luxuriantly on the outside of Mr. Geg's Mothouse at Hampton. 


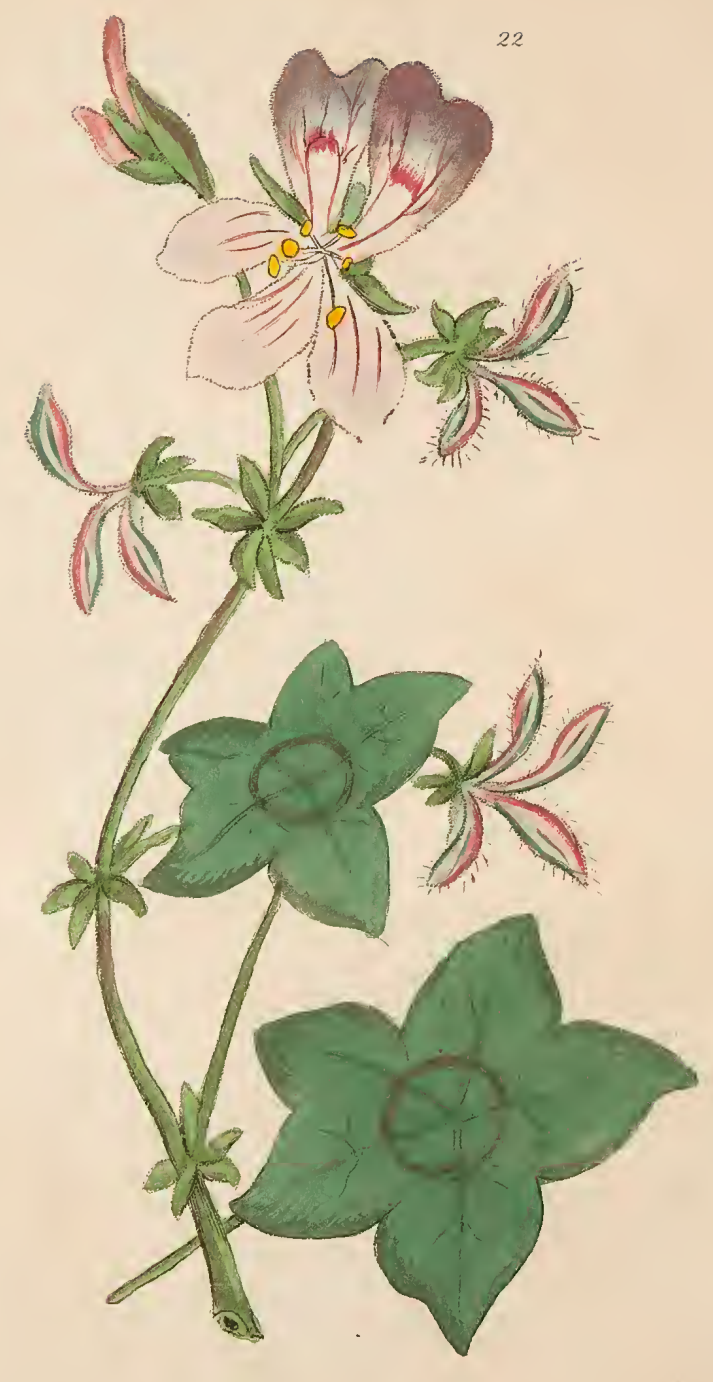

IVY-LEAVED GERANIUM.

Lat: Geranium Pettatum.

Cl: MONADELPHIA.

Ord: D E C A N D R I A.

This is one of the Geraniums which come from Africa.

It is of the Herbaceous kind, but not so tender as many others; and it is easily propagated by cuttings from shoots of a year old; also by seeds.

Plant the cuttings from March till July; the seeds should be sown in April.

Geranium Iry-Lerned. 
RIGID-LEAVED GORTERIA.

Lat: Gorteria Rigens.

$\mathrm{Cl}$ : SYNGENESIA.

Ord: POLYGAMIA FRUTRANEA.

The Gorteria is a native of the Cape; the brilliancy of its blossom renders it a great acquisition to the Green-house.

It flowers in May, June, and July; is propagated by cuttings in the summer, which should be planted in a Hot-bed.

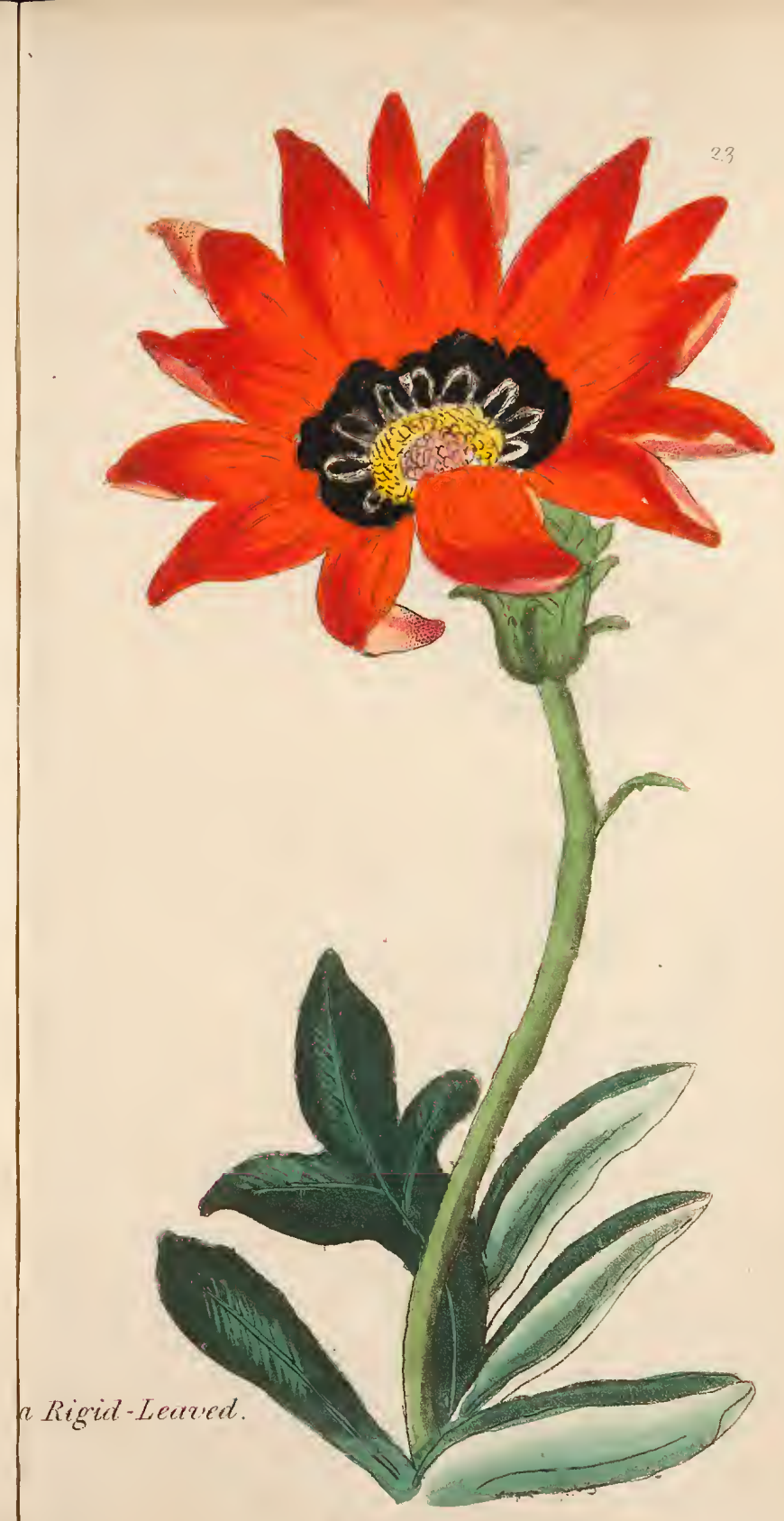




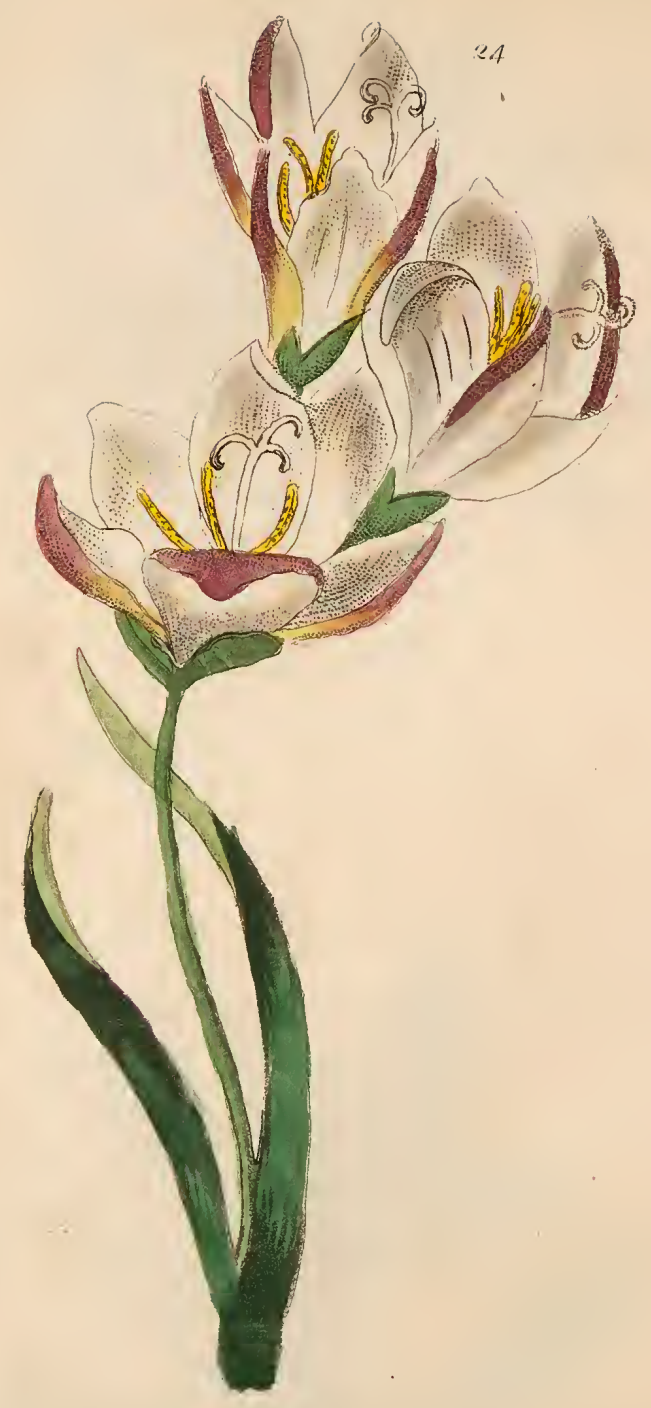

YELLOW-FLOWERED GEISSORPHIZA.

Lat: Geissorphiza Obtusata.

Cl: TRIANDRIA.

Ord: MONOGYNIA.

As this plant is a native of a warm climate, it requires the shelter of a garden-frame, or of a Green-house, during the winter.

It flowers in May: and when the leaves and stalks decay, then is the proper time to transplant the roots, or to propagate them by offsets.

Geissorphiza Yellow-Leaved. 
BECURVED MEATH

Lat: Erica Retorta.

Cl: OCTA N DRIA.

Ord: MONOGYNIA.

This beantiful Heath still continues to be as very scarce pliant.

It fowers in $\Lambda$ ugust, and is eucreased by euttings, which are much assisted by being placed in a Hot-bed.

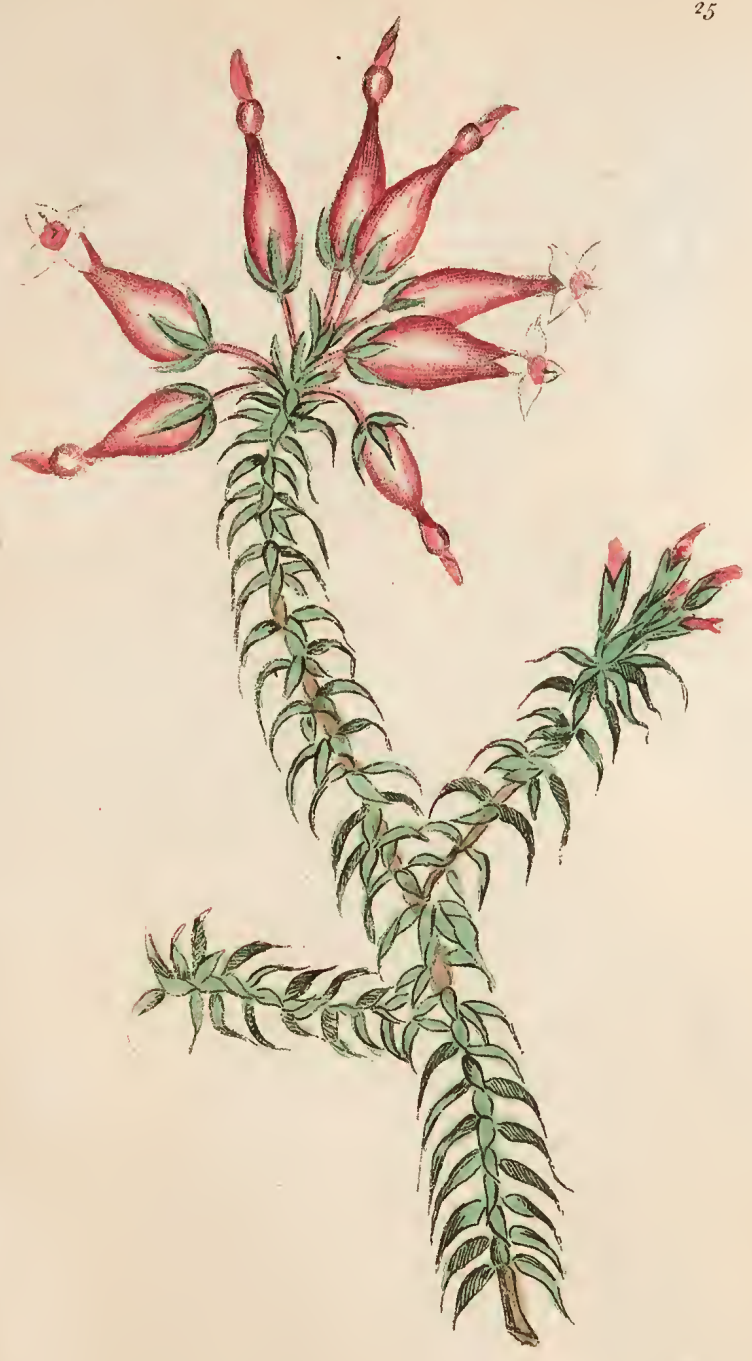

Heath Recurved. 


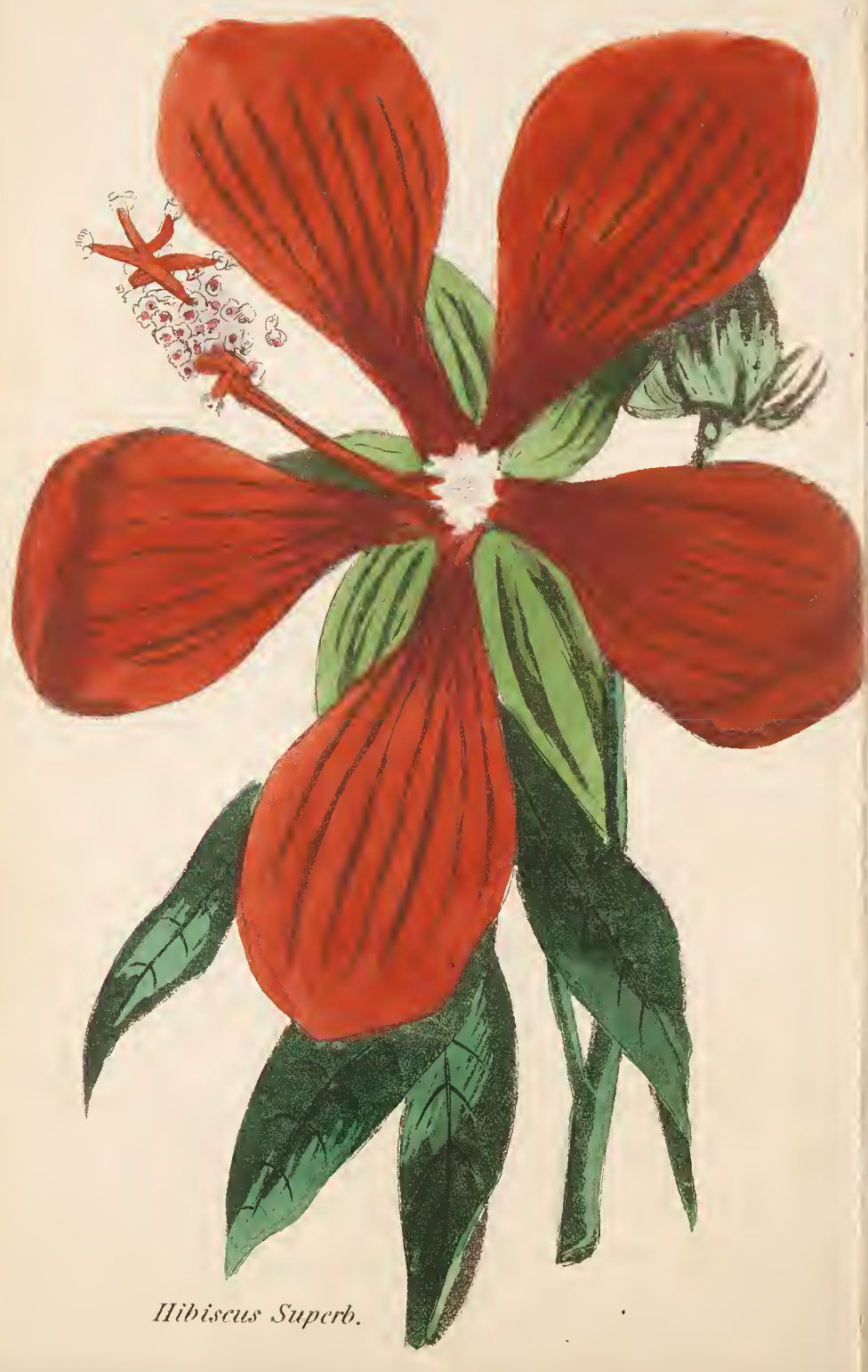

SUPERB HIBISCUS.

\section{Lat: Hibiscus Speciosus.}

Cl: MONADELPHIA.

Ord: POLYANDRIA.

This magnificent plant came from Carolina : formerly it was always treated as a Stove-plant, but it is now most frequently to be seen in the Green-house.

It flowers in August, and is propagated by seeds, which require the assistance of the Hotbed. 
GREEN-STAINED IXIA.

Lat: Ixia Maculata,var Viridis $(Y)$.

Cl : TR I A N DR IA.

Ord: MONOGYNIA.

This plant is much valued for the singularity of its colour.

It blossoms in May, June, and July, and requires the same treatment as other Ixias.

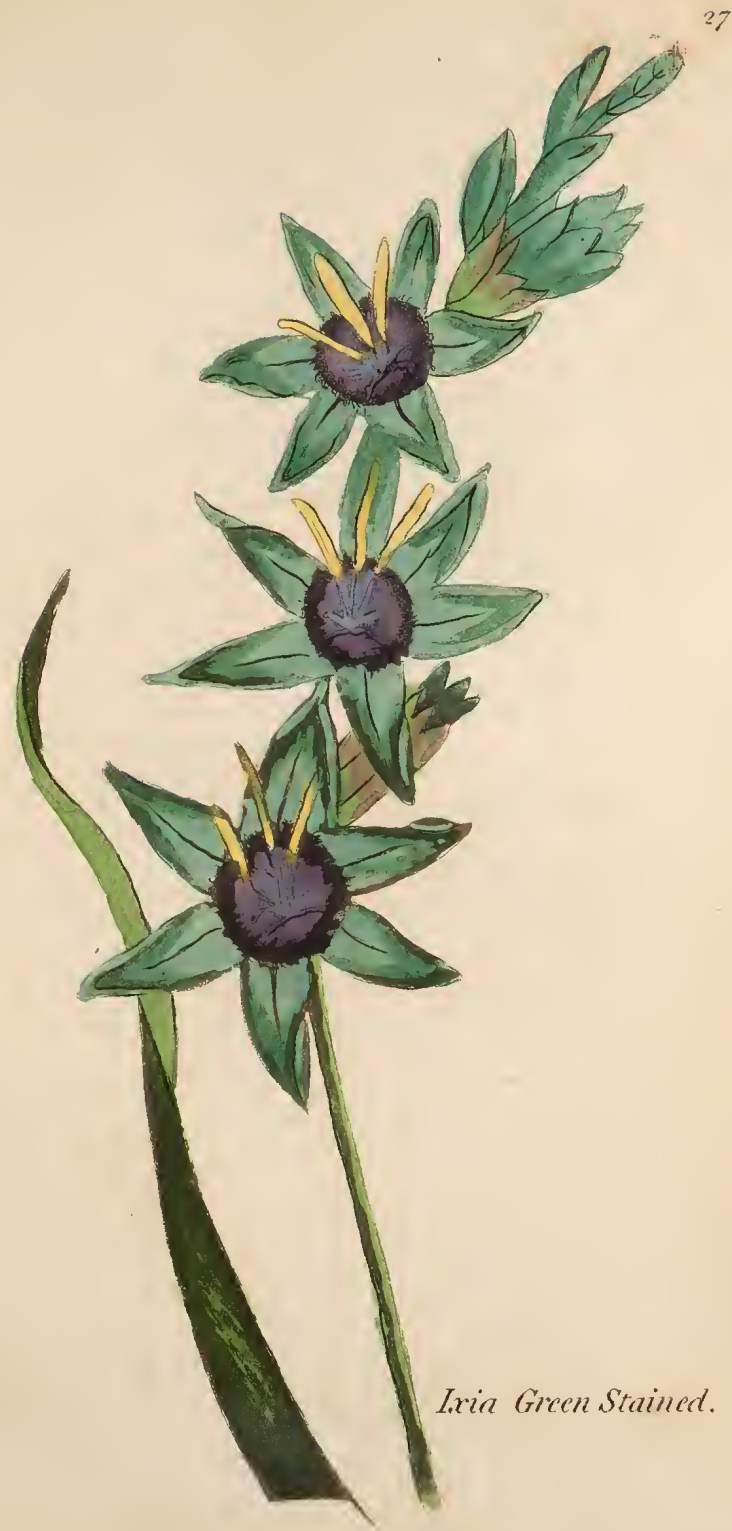




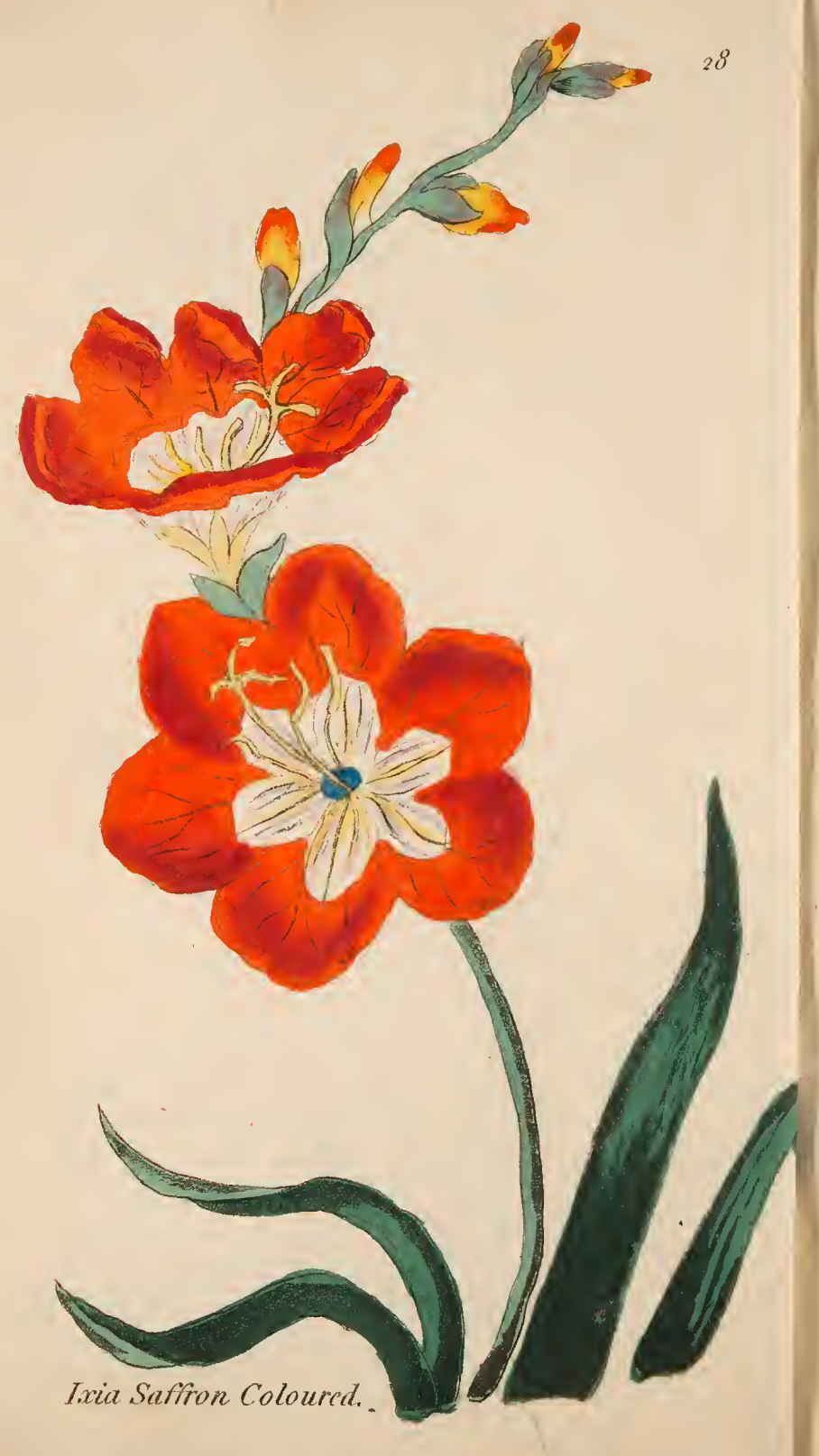

SAFFRON-COLOURED IXIA.

Lat: Ixia Crocata.

Cl : TRIA N D R I A.

Ord: MONOGYNIA.

The Ixias in general being natives of a warm climate, require in this country to be kept in pots, and sheltered either in the Frame, or Green-house during the Winter.

They flower in May, Jume, and July, like other bulbous roots: they produce their leave and flowers in the Spring, and decay in the Summer and Autumn; which is the proper time to transplant the roots, and to propagate them by offsets. 


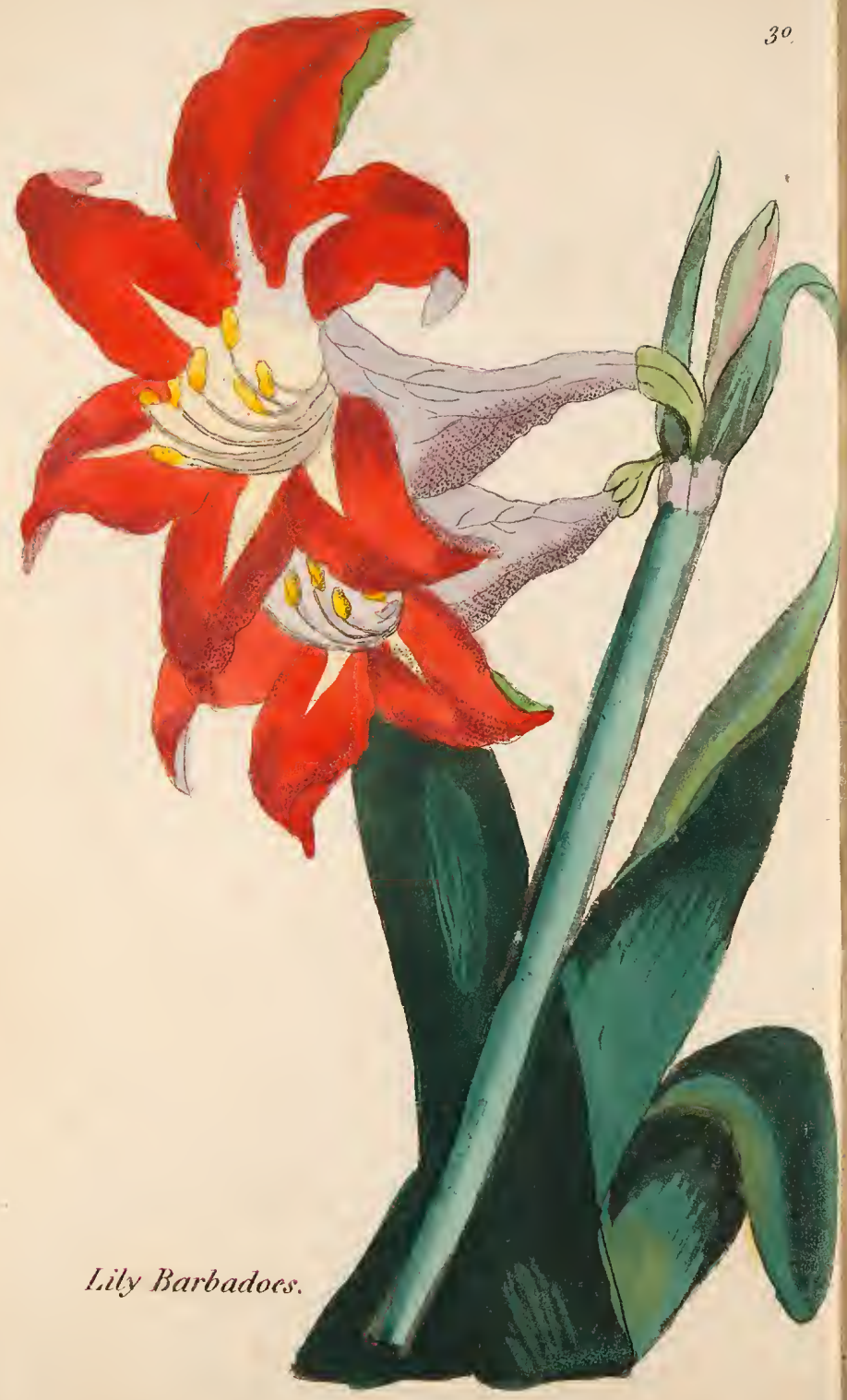

BARBADOES AMARYLLIS, OR LILY.

Lat: Amaryllis Equestris.

Cl: HEXANDRFA.

Ord: MONOGYNIA.

This being a very tender plant requires much care.

It flowers in April, and is propagated by offsets, taken from the root, when the leaves decay.

It succeeds best in light earth. 


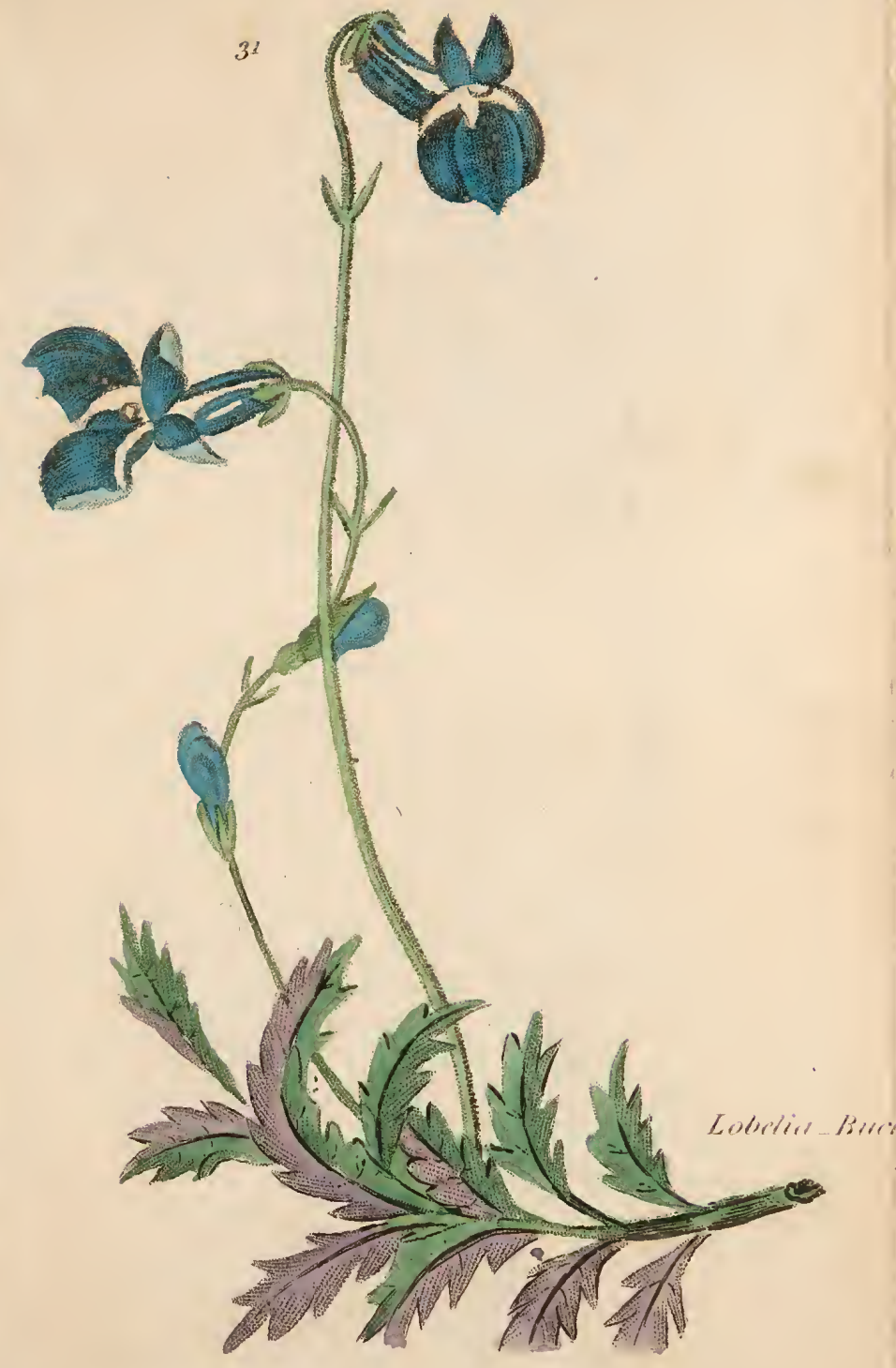

This plant deserves admittance into all collections, for the great beauty of the flower, which opens in July and August.

It may be propagated by seeds sown in boxes, to defend it from the frost, or, by cuttings of the stalks in June; also by offsets in September or in March. 
EARGE-FLOWERED MONSONIA.

Lat: Monsonic Speciose.

CI: POLYADELPHIA.

Ord: DODECAN DRIA.

This beautiful plant is a native of the Cape: it is much esteemed for its elegant fower.

It is a hardy Green-house plant, and shoud be raised from seeds.

Monsonin_Larew Flowerd. 
PURPLE MAGNOLIA;

Lat: Magnolia Purpurea.

Cl: POLYANDRIA.

Ord: POLYGYNIA.

The purple Magnolia is regarded as a hardy Green-house plant, which came from China, and grows to a considerable height.

It is propagated by seed, layers, and cuttings, which slould be placed under glasses in their infant state.

The seed succeeds best when sown in light earth, and placed in a Hot-bed.

This plant requires shelter in the Winter, and sliade in the Summer.

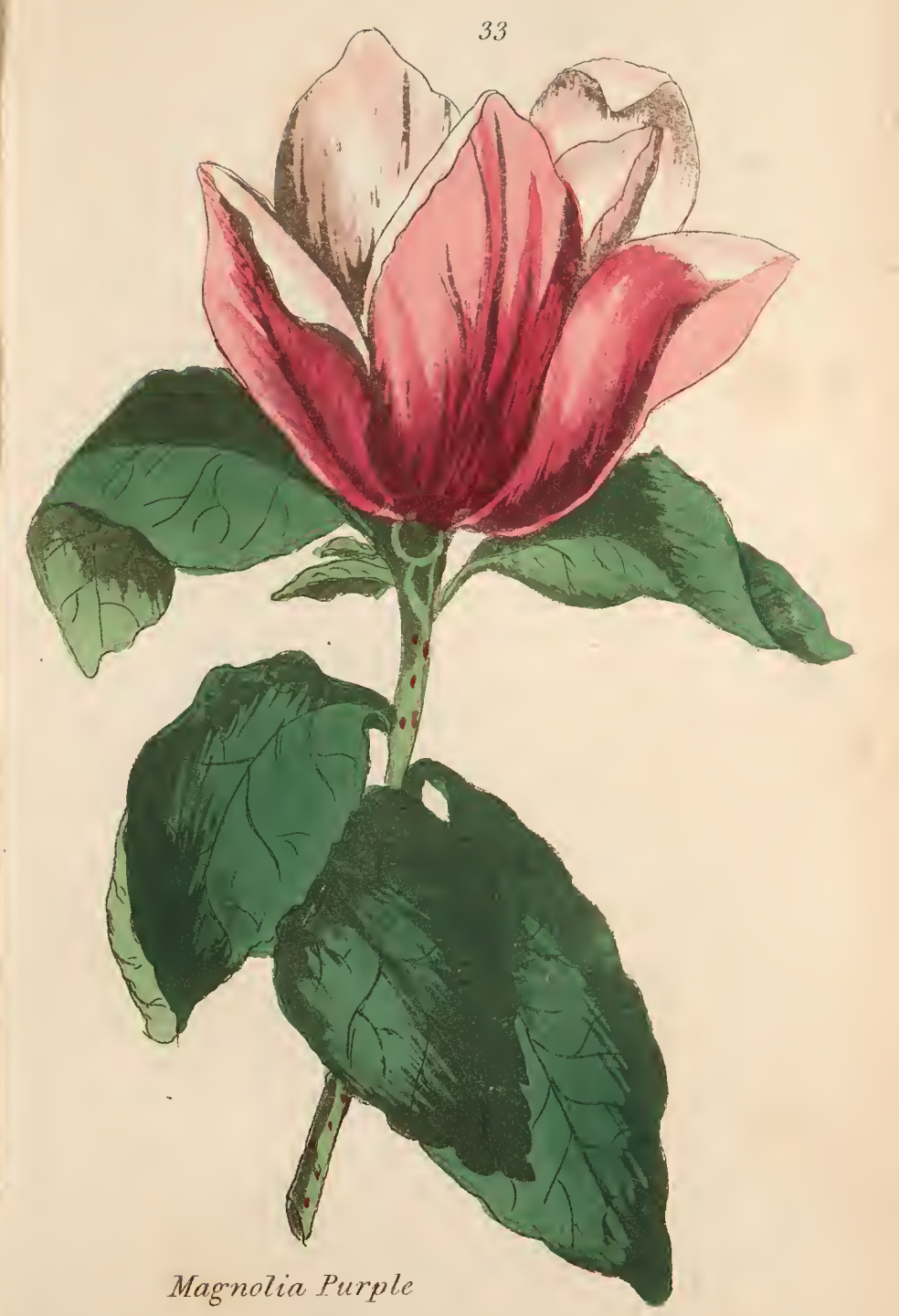


PURPLE MAGNOLIA;

\section{Lat: Magnolia Purpurea.}

Cl: POLYANDRIA.

Ord: POLYGY N IA.

The purple Magnolia is regarded as a hardy Green-house plant, which came from China, and grows to a considerable height.

It is propagated by seed, layers, and cuttings, which slould be placed under glasses in their infant state.

The seed succeeds best when sown in light earth, and placed in a Hot-bed.

This plant requires shelter in the Winter, and shrade in the Summer.

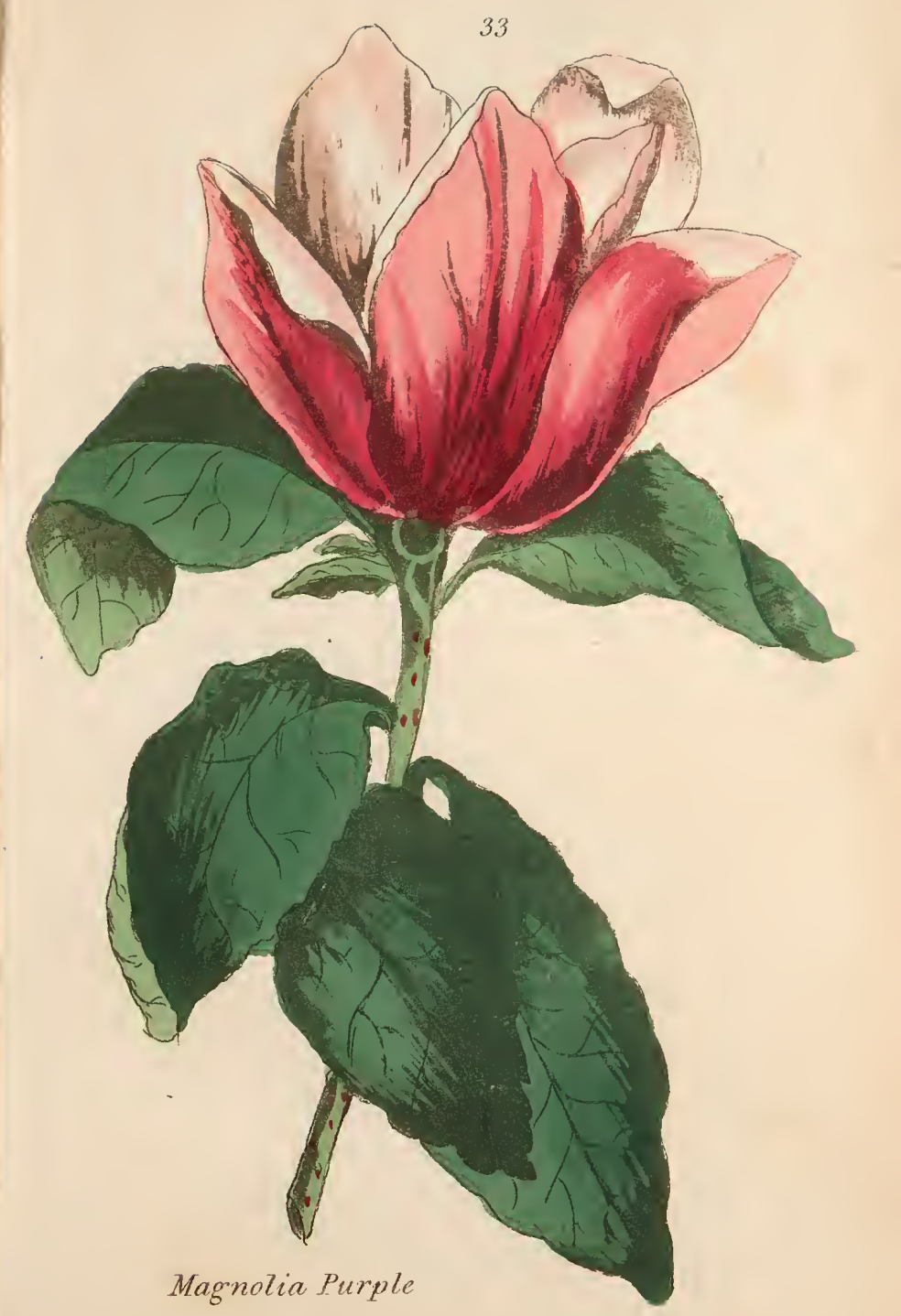


WHORLED-LEAVED MIMOSA.

Lat: Mimosa Verticillata.

CI: POLYGAMIA.

Ord: MONOECIA.

This plant does not arrive at perfection till after several years growth; it comes from Botany Bay, and is propagated by seed, which must be sown in a Hot-bed.

It succeeds best in the Green-house, 
CLIMBING MAURANDYA, OR BASTARD FOX-GLOVE.

Lat: Maurandya Semper Florens.

ㄹ: DID Y AMIA.

Ord: A NGIOSPERMIA.

This pretty flowering shrub, whieh grows to six feet and upwards in height, blossoms from the beginning of the Summer 'till the Aubamn, aftording an ormamentat variety to the Green-house.

It is propagated by seeds sown in the Spring, or in the Autumn.

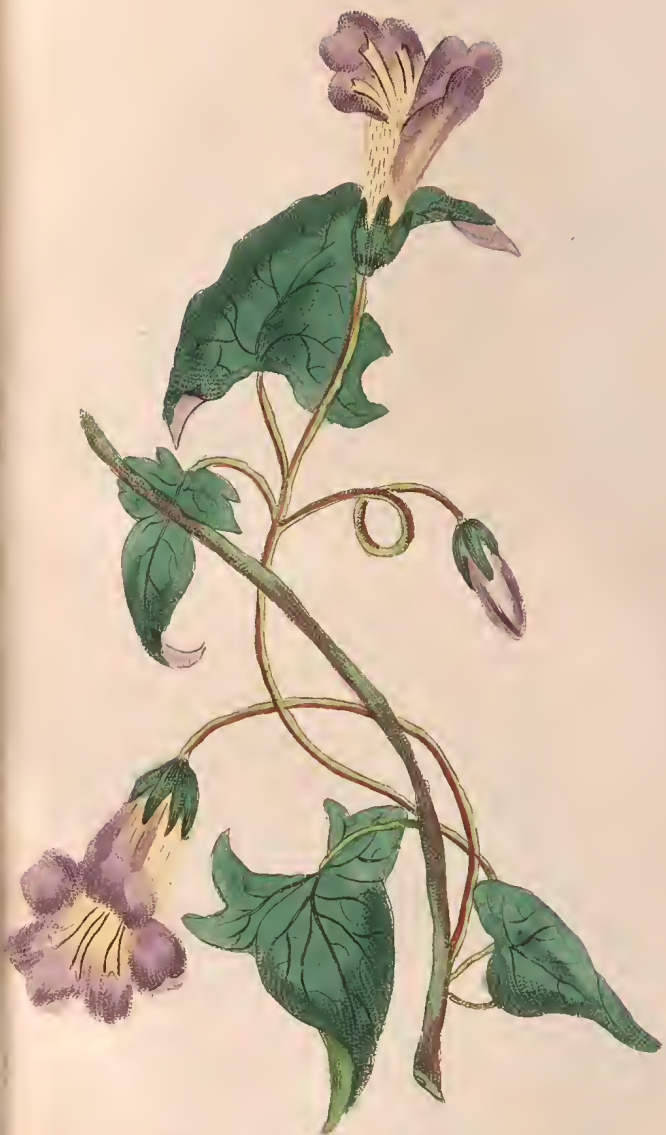

Maurandya Bastard For. Glove. 
SIIRAL-FLOWERED MORAEA.

Lat: Maraea Spiralis.

Cl: T R I A N D R I A.

Ord: MONOGYNIA.

The Moraea Spiralis, came from the Cape.

It blossoms in June and July: in genern it is propagated by offsets, and also by seeds. 
NEAPOLITAN MEZEREON.

Lat: Daphne Collina.

CI : OCTANDRYA.

Ori: MONOGYNIA.

This is a hardy plant.

Its beantiful foliage and agreeable perfume, render it a great acquisition to the Green-house.

It flowers in February, and is in general encreased by being grafted on common Mezerenn.

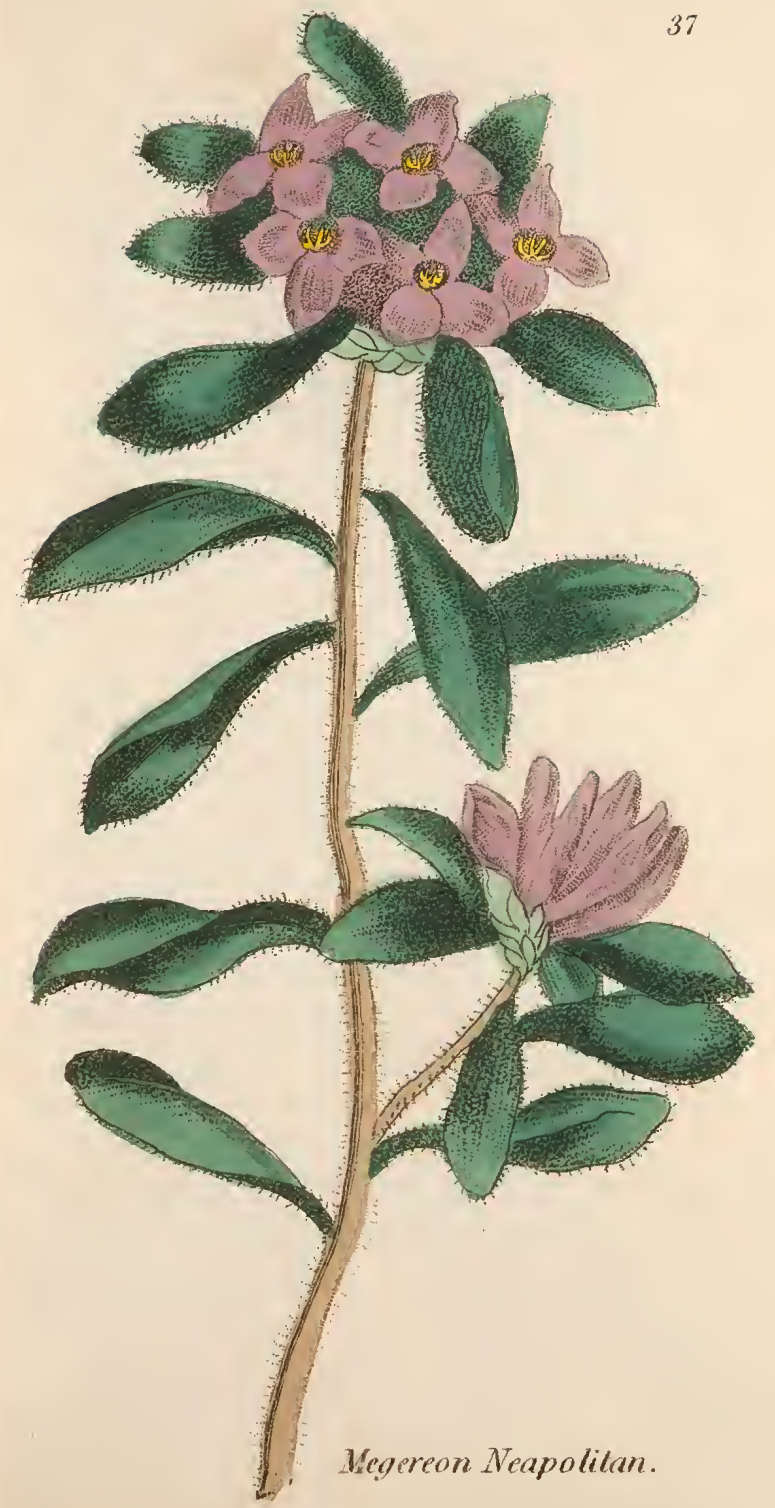




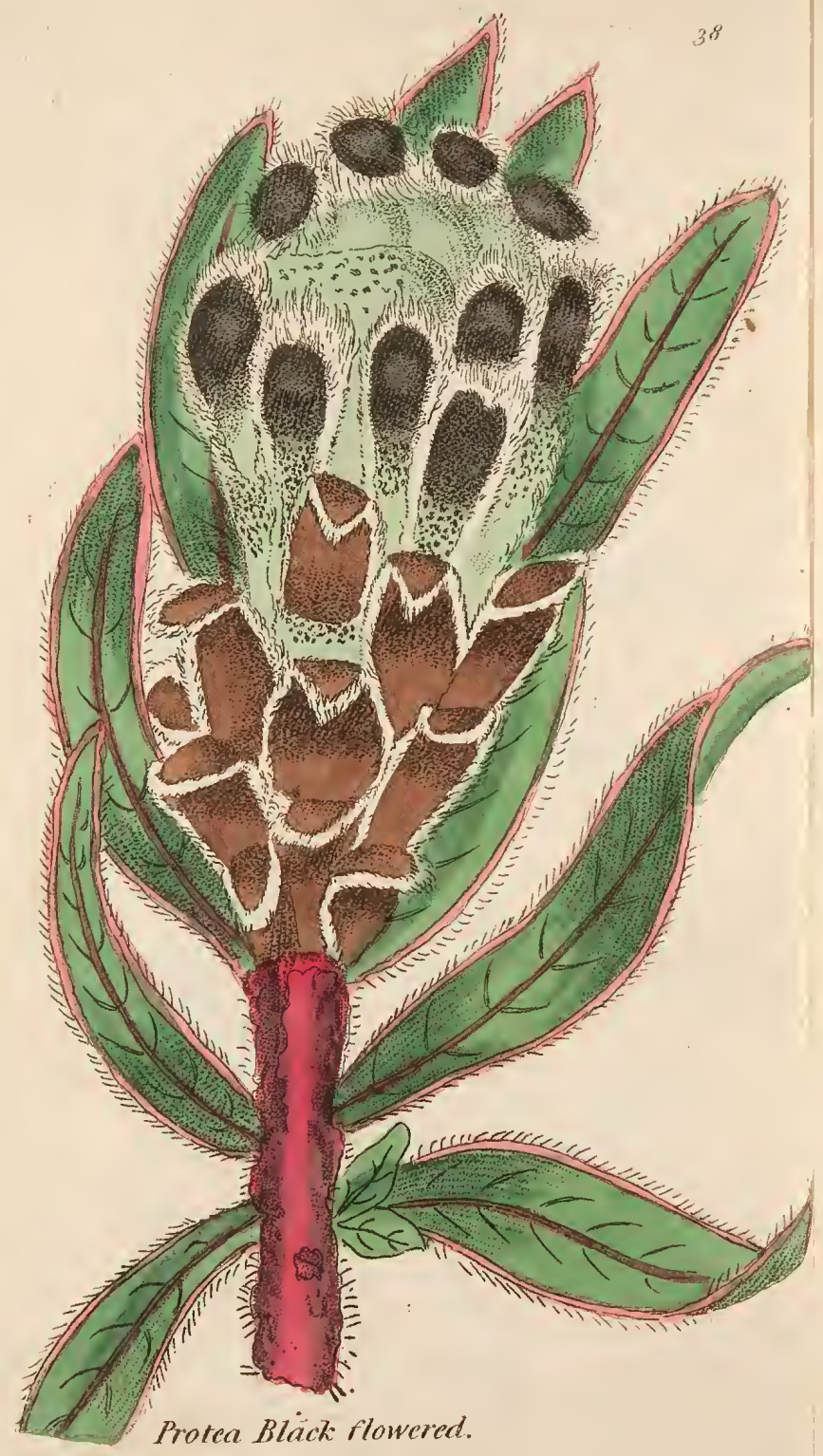

BLACK-FLOWERED PROTEA.

Lat: Protea Lepidocarpon.

Cl: 'TETRANDRTA.

Ord: MONOGYN IA.

The Protea Lepidocarpon has a singular foliage, it requires the warmth of the Greenhouse in Winter.

It is encreased by cuttings, which should be placed in a Hot-bed. 


\section{HEART-LEAVED PROTEA.}

\section{Lat: Protea Cordifolia.}

\section{Cl: TETRAN DRIA.}

Ord: MONOGYNIA.

This singular plant is much admired for the variety of its beautiful foliage.

It is propagated by seeds, in the Spring, which should be sown in pots, and placed in a gentle Hot-bed; also by cuttings.

This plant requires being placed in an airy part of the Gren-house.

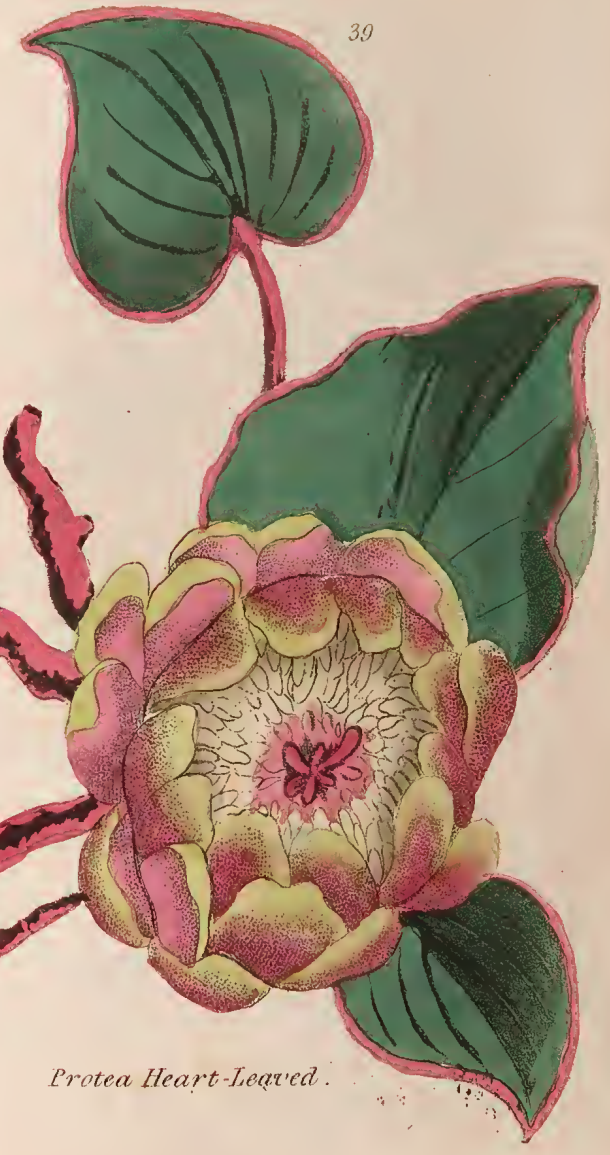




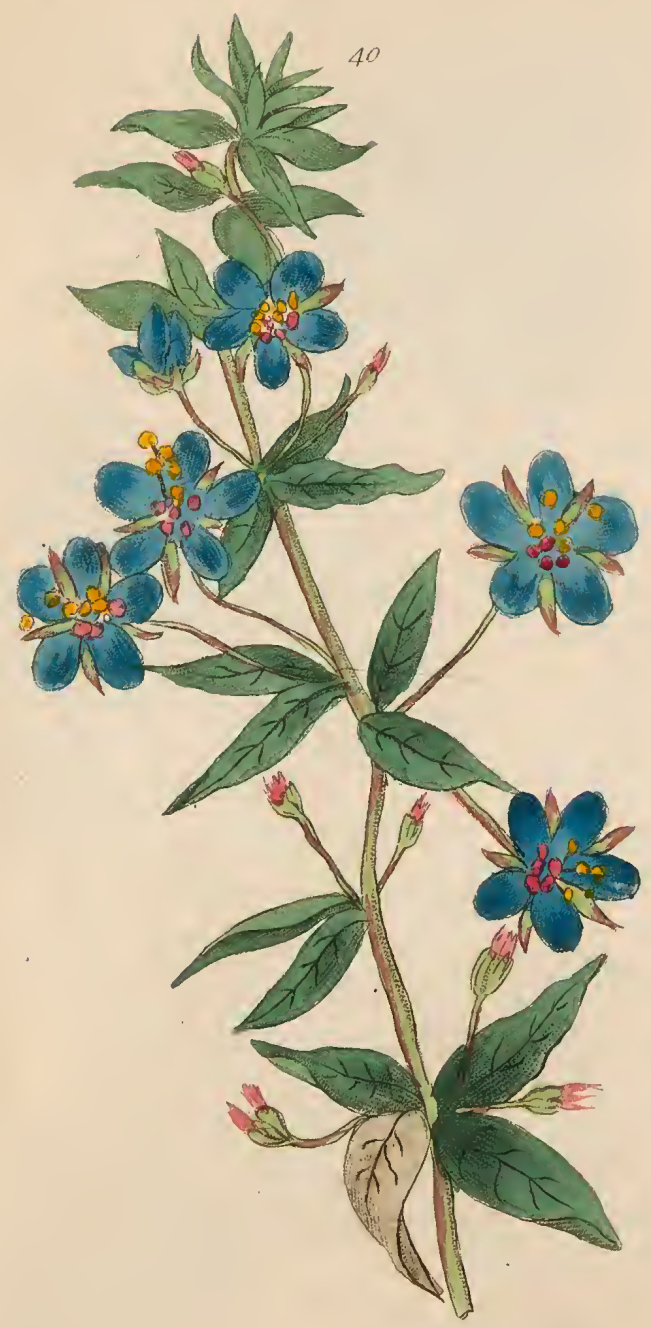

ITALIAN PIMPER YEI.

Lat: Anagallis Monellis.

Cl: PEN'TANDRIA.

Ord: MONOGYNA.

In Italy this plant grows most luxuriantly, and the beauty of its flower renders it very ornamental in a Green-house, particularly as it continues in blossom during most of the year.

It is propagated by cuttiugs.

Pimpernel Italian. 
41

DWARF POMEGRANATE TREE.

Lat: Punica Nana.

CI: ICOSANDRIA.

Ord: MONOGYNIA.

The Punica Nana, should be placed in every Green-house, as it is an ornamental shrub, which blossoms beautifully in the Summer and Autumn, and is easily encreased by cuttings.

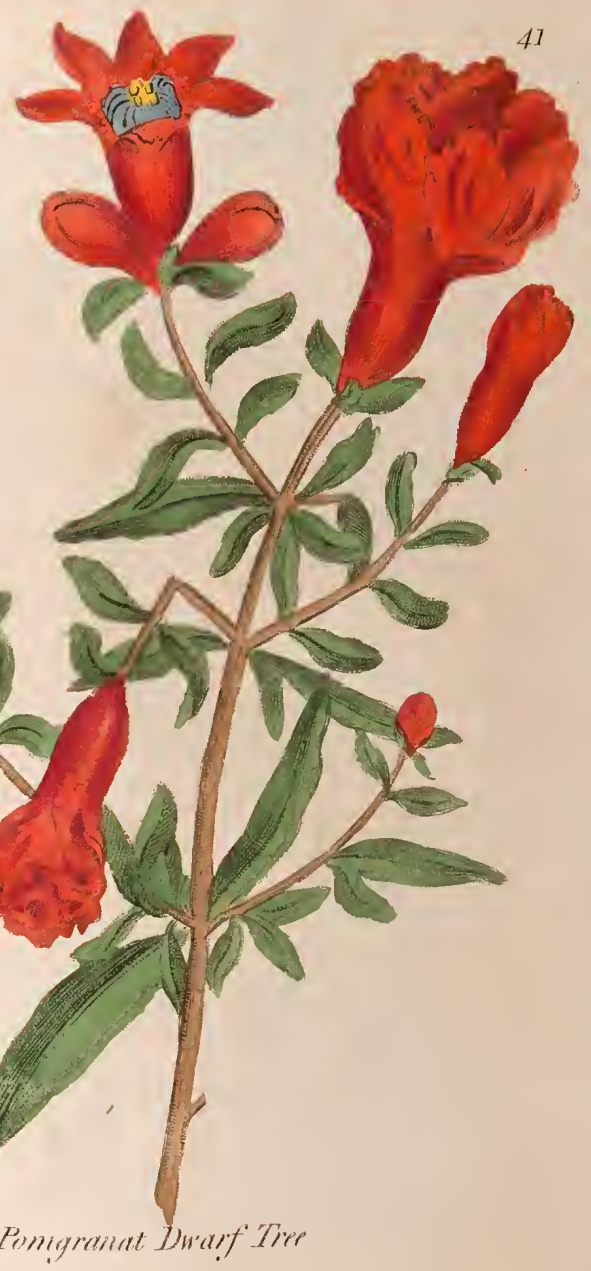




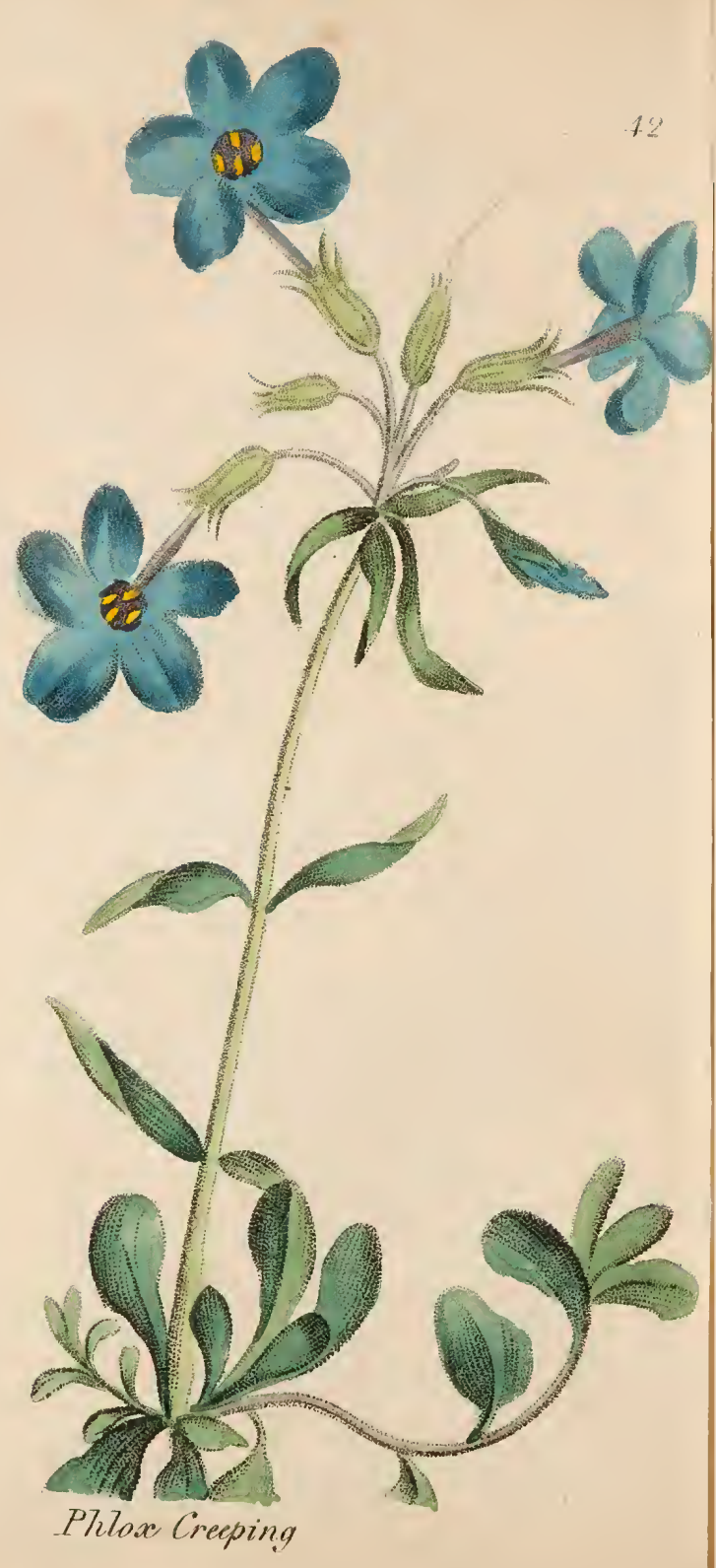

CREEPING PHLOX.

Lat: Phlox Stolonifera.

Cl: PENTANDRIA.

Ord: MONOGYNIA.

The foliage and blossom of this plant, are extremely elegant, and it would be very ornamental, to adom rock-work; but although a hardy plant, yet it requires shelter from the severe frost of this climate.

It is propagated by seeds and by cuttings. 
43

FIDDLE-LEAVED PHYSIC NUT.

Lat: Satropha Panduraefolia.

CI: MONAECIA.

Ord: MONADELPHIA.

This elegant shrub grows wild in the West Indies.

It continues in flower great part of the year, and is raised by seed, and also by cuttings, which are much forwarded by a Hot bed.

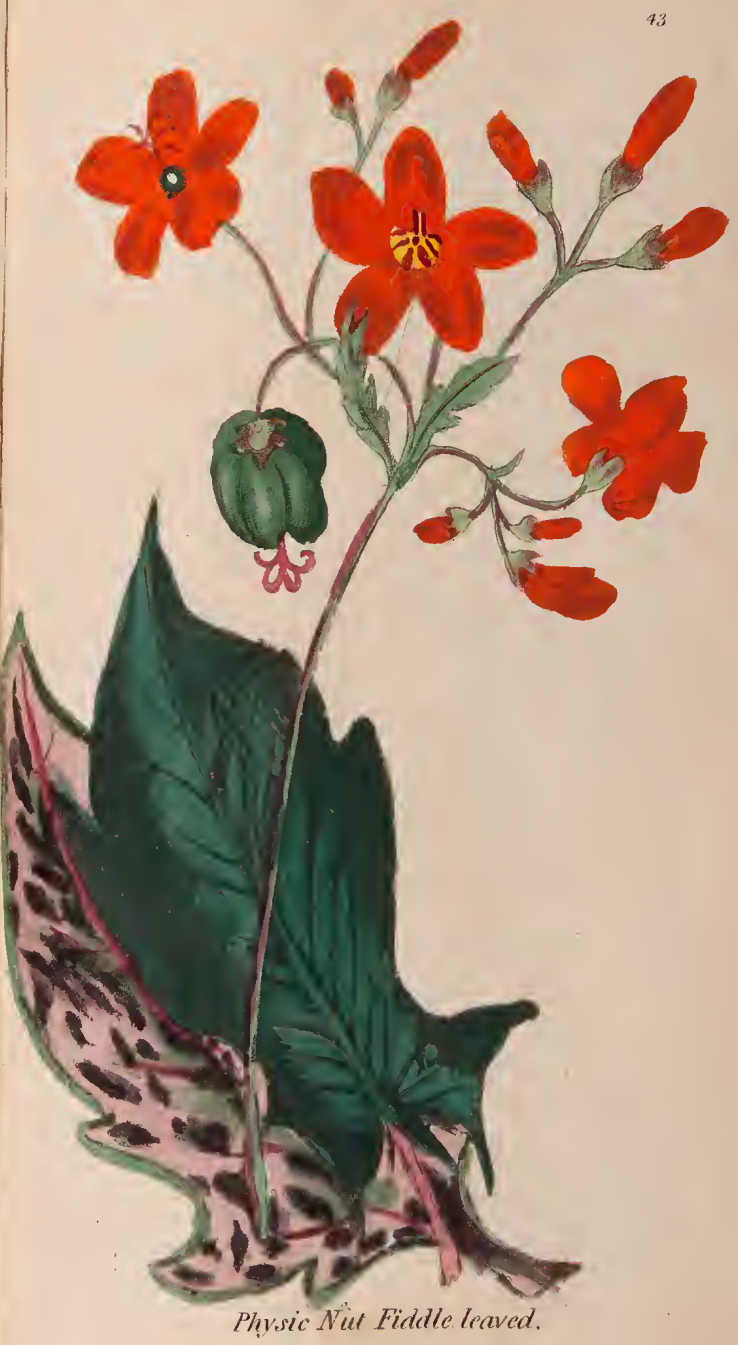


BLUE SOPHORA.

Lat: Sophora Australis.

Cl: DECA N DR IA.

Ord: MONOGYNIA.

This is a hardy plant, which will some times succeed in a warm border; it is a native of Asia and America.

It is easily raised by seeds, or bv cuttings.

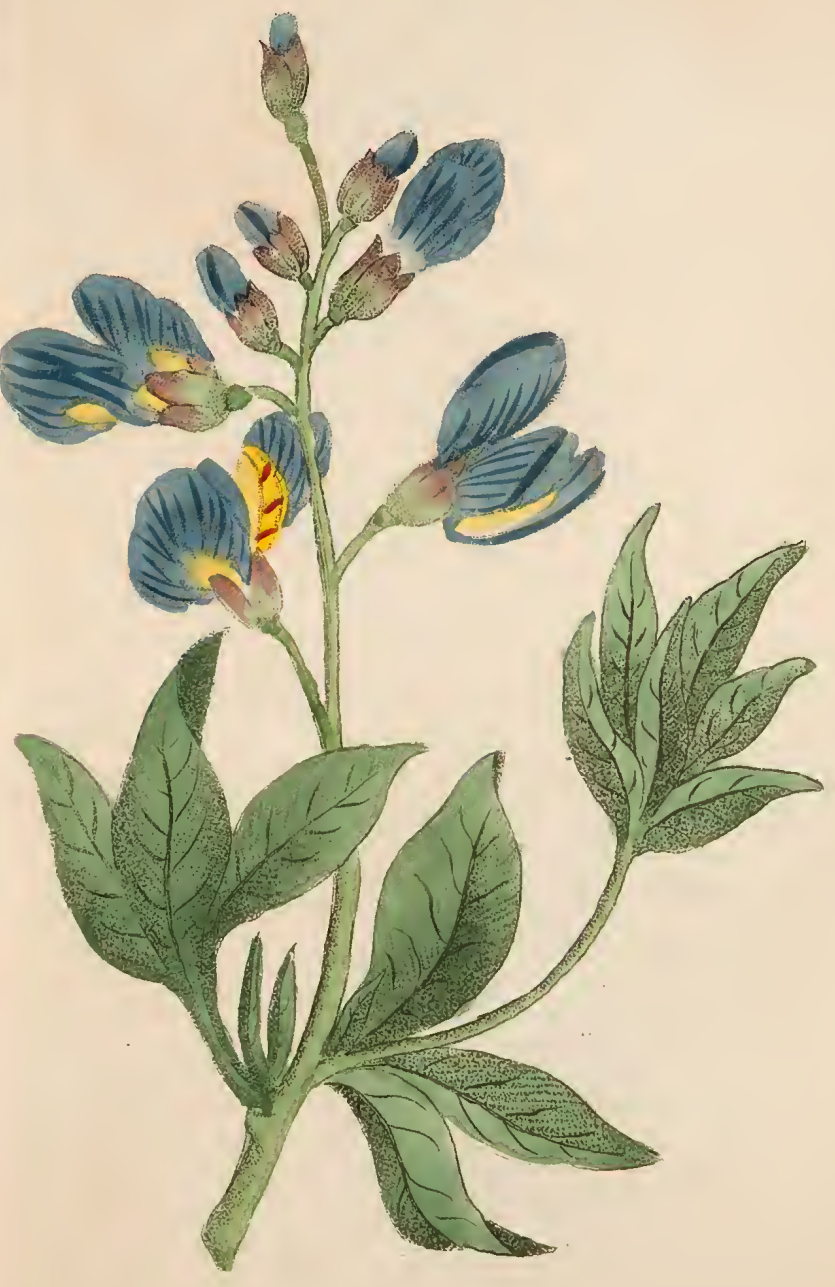

Serpleara Blue. 
COMMON INDIAN REED, OR SPOT.

Lat: Canna Indica.

Cl: MONANDRIA.

Ord: MONOGYNIA.

The Canna Indica is a native of Asia, Africa, and America, where it continues in flower all the year: but in this Climate it blossoms only in June, July, and August.

It is propagated by seeds, which should be sown in the Spring, and placed in a warm part of the Green-house. 
SHINING-LEAVED SAGE.

Lat: Salvia Formosa.

Cl: D IA N DR IA.

Ord: MONOGYNIA.

This delightful Sage came from Peru, and it should be kept in a warm part of the Green-liouse.

It is expeditiously encreased either by cuttings or slips; which should be placed in a Hot-bed in the Spring of the year.

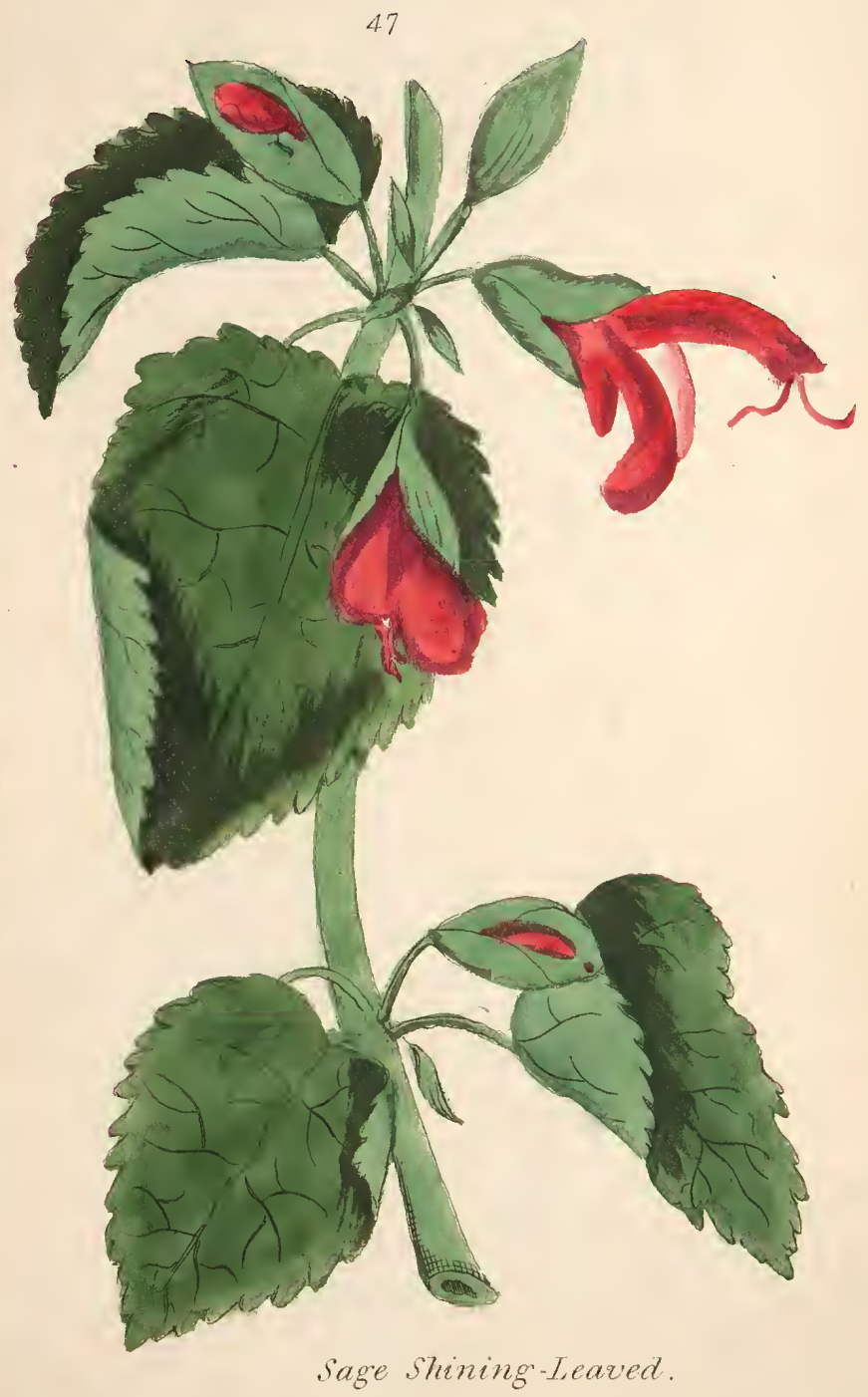




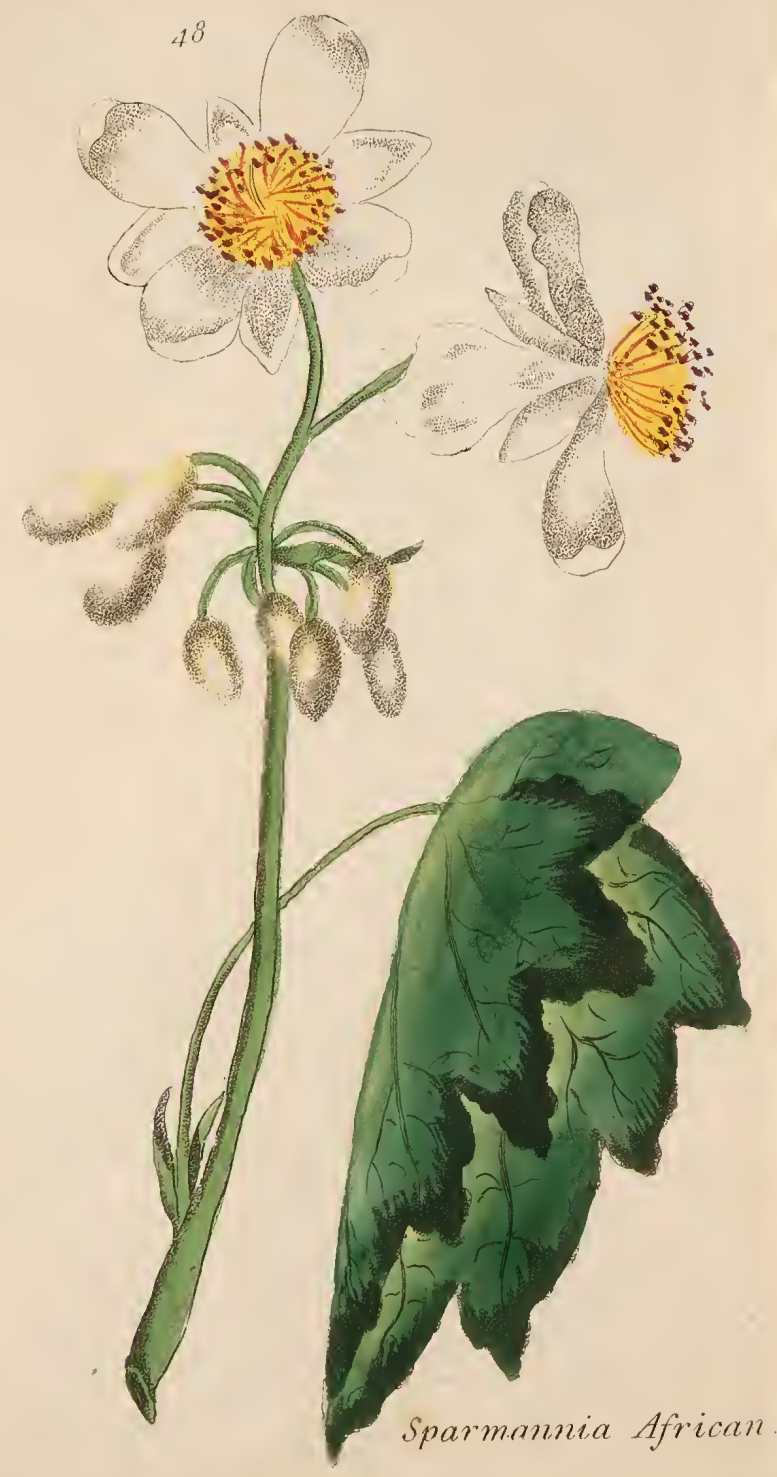

AFRICAN SPARMANNIA.

Lat: Sparmannia Africana.

Cl: POLYANDRIA.

Ord: MONOGY NIA.

This elegant tender Shrub came from the Cape, and is at present very scarce.

It is propagated by cuttings. 
ROSE VERVAIN.

Lat: Verbena Aubletia.

Cl : D I A N D R IA.

Ord: $M O N O G Y N I A$.

The Verbena is generally found in most Green-liouses, as the brilliancy of its colour makes it a desirable acquisition.

It blossoms in June and July, and may be propagated either by seeds, cuttings, or layers, which reciuire being placed in a Hotbed.

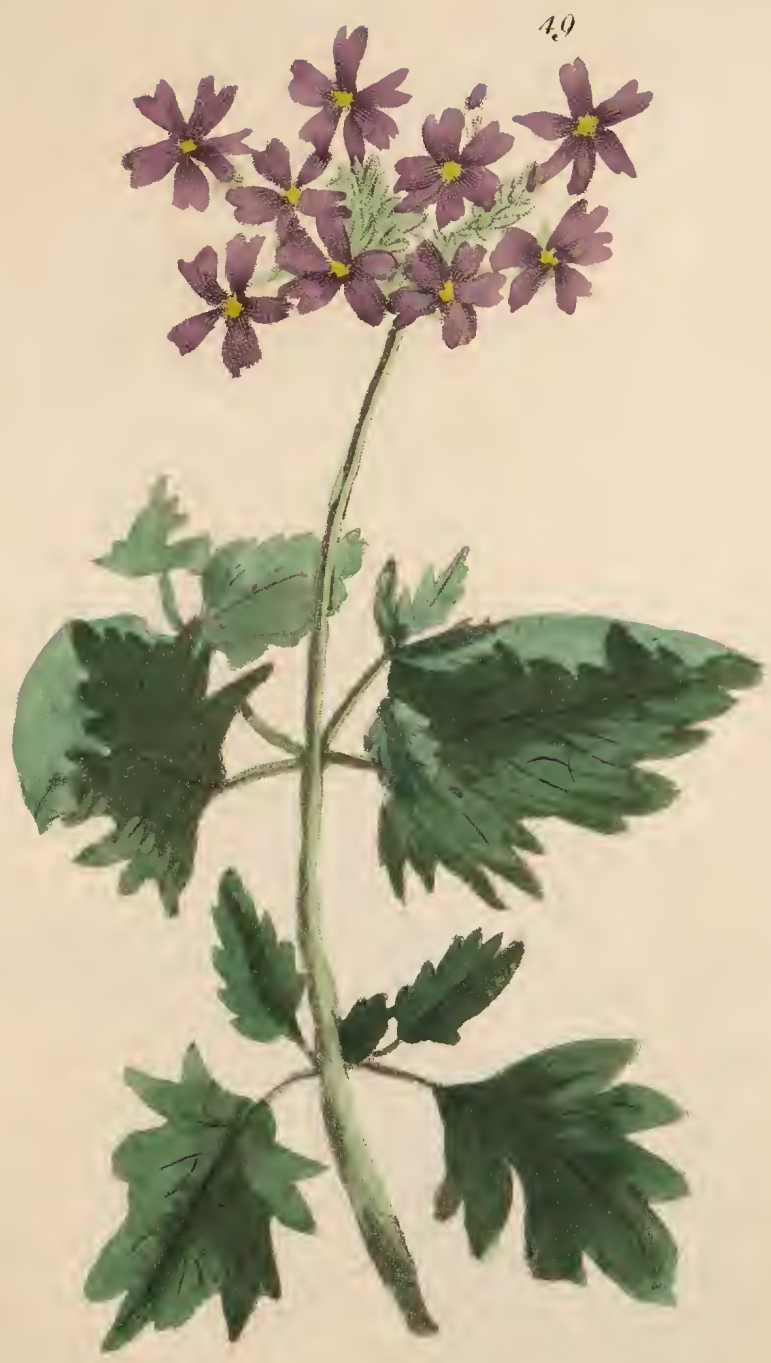

Vervin Rose. 


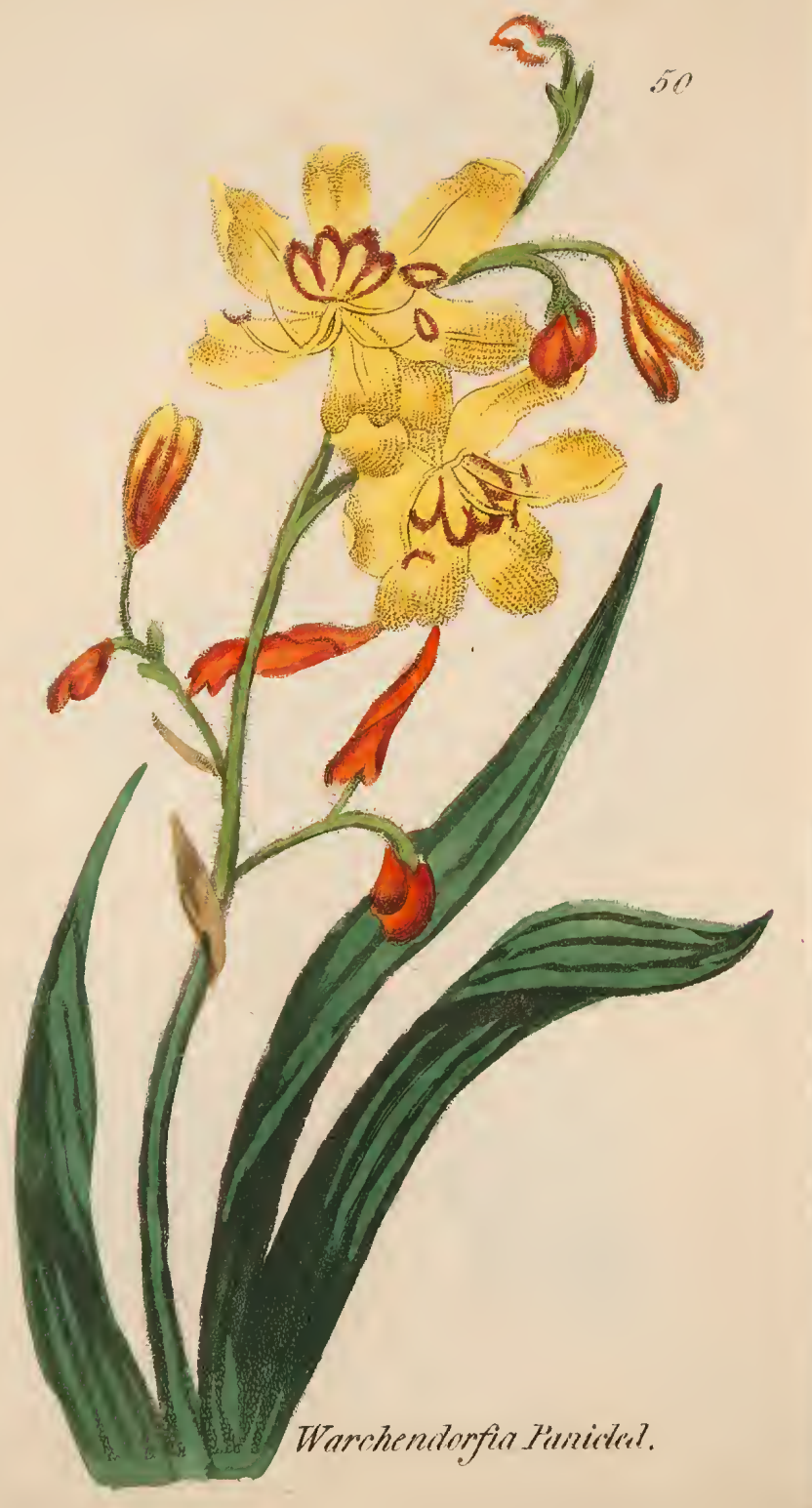




\title{
INDEX
}

OF THE CLASSES TO WHICH EACH

FLOWER BELONGS.

\author{
$\longrightarrow$ \\ CLASS. 1. \\ MONANDRIA. \\ Canna Indica. \\ 2. \\ DIANDRIA. \\ Salvia Formosa. \\ Verbena Aubletia.
}

3.

TRIANDRIA.

Geisorphiza Obtusata.

Wachendorfia Paniculata.

Moraea Spiralis.

Ixia Maculata.

Ixia Crocata.

Gladiolous Blandus (var. B.) 
INDEX.

4.

TETRANDRIA.

Buddlea Globosø.

Protea Lipidocarpon.

Protea Cordifolia.

5.

PENTANDRIA.

Convolvulus Althaoiedes.

Convolvulus Cairicus.

Chironia Decussata.

Phlox Stolonifera.

Cyclamen Persicum.

Anagallis Monelli.

Crassula Coccinea.

6.

HEXANDRIA.

Amaryllis Equestris.

gapantheis Umbellatus.

Lillium Philadel phian.

Aloe Variegata.

8.

OCTANDRIA.

Fuchsia Coccinea.

Daphue Collina.

Erica Retorta.
INDEX.

10

DECANDRIA.

Silene Ornata.

Dais Cotinifolia.

Saphora Australis.

Saphora Tetraptera.

12.

ICOSANDRIA.

Punica Nana.

Cactus Flagelliformis.

13.

POLYANDRIA.

Caparis Spinosa.

Sparmanuia Africana.

Monsonia Speciosa.

Magnolia Purpurea

14.

DJDYNAMIA.

Maurandya Sempertlorens.

16

MONADELPHIA.

Aitonia Capensis.

Hibiscus Speciosus. 


\section{ENGLISH INDEX.}

INDEX.

Geranium Peltatum.

Camellia Japonica

17.

DIADELPHIA.

Collutea Frutescens.

Coronilla Glauca.

Crotalaria Triflora.

19.

SYNGENESIA

Chrysanthemum Indicum.

Goteria Rigens.

Lobelia Coronopofolia.

20.

GYNANDRIA.

Calla Palustris.

21.

MONOECIA.

Jatropha Pandurafolia.

23.

POLYGAMIA.

Mimosa Verticillata.

THE END.
A sapanthus, or Blue Lily............... i

Aitonia, Cape .....................

Aloe, Partridge-breast................... s

Arum, Marsh Bastard...................

Bind-weed, Fgyptian. ................

Buddlea, Round-headed................. 6

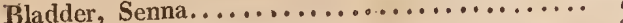

Crassula, Scarlet-flowered ................ 8

Catch-fly, Dark-coloured.................. 9

Crotaria, Three-flowered................. 10

Cereus, Creeping. ..................... 12

Cyclamen, Persian................... 19

Coronilla, Day-smelling................ 13

Convolonlus, Silky-leaved................ 14

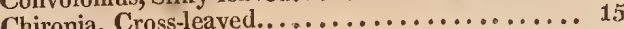

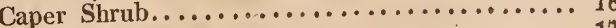

Camillia, Rose $\ldots \ldots \ldots \ldots \ldots \ldots \ldots \ldots \ldots \ldots \ldots 18$

Corn-flag, Snow-white.................. 1

Chrysanthemum, Indian................ 19

Chy

Dais, Cotinus-1eaved . .................... 21

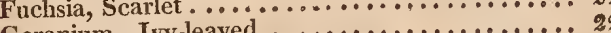

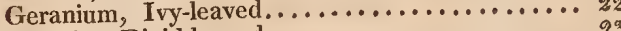

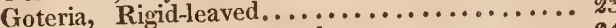

Geissorphiza, Yellow-leaved...............

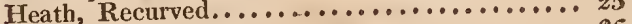

Hibiscus, Superb. ................... 26

Ixia, Green-stained. ................... 27

Ixia, Saffiron-coloured. ................ 28

Eily, Philadelphian. ................... 29

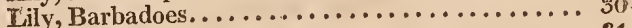

.

.

Ma

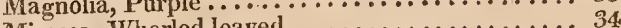

Mimosa, Whorled-leaved,................. 34

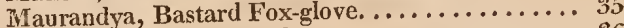

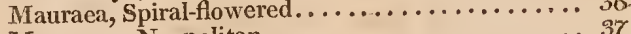

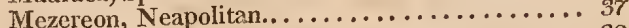

Protea, Black-Elowered................ 38

Protea, Heart-leaved . . . . . . . . . . . . ... 59

Pimpernel, Italian. ..................

Pongranate Dwarf-tree............... 41

Phlox, Creeping. ............................ 43

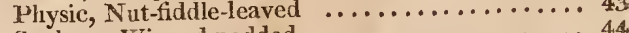

Saphora, Winged-podded............... 4 .

Saphora, Blue ...................... 45

Shot-Indian Reed, or Shot ............. 46

Sage, Shining-leaved.................. 47

Sparmannia African $\ldots \ldots \ldots \ldots \ldots \ldots \ldots \ldots \ldots \ldots$

Vervain Rose........... 49

Worchendorfia, Panicled .................. 50 


\section{LATIN INDEX.}

Agapanthus, Umbellatus.

Aitonia, Capensis $\ldots \ldots \ldots \ldots \ldots \ldots \ldots \ldots$

Aloe, Varierata . . . . . . . . . . . . . . . . .

Amaryllis, Equestris. . . . . . . . . . . . . . . .

Anamallis, Monelli. ..........

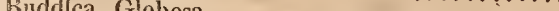

Collutea, Frutescens. . . . . . . . . . . . . . . .

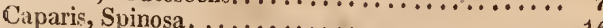

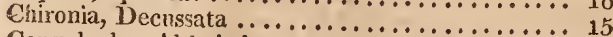

Convolvulus, Althoiedes. .......................... 15

Convolvulus, Cairicus. ............................. 14

Camellia, Japonica.........................

Coronilla, Glauca ....................... 13

Cyclamen, Persicum .....................

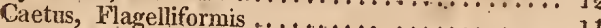

Crassula, Coccinea $\ldots \ldots \ldots \ldots \ldots$

Canna, Indica ...........................

Crotalaria, Triflora $\ldots \ldots \ldots \ldots \ldots \ldots \ldots \ldots \ldots \ldots \ldots \ldots \ldots \ldots$

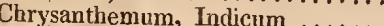

Calla, Palustris .........

Daphne, Collina .................. 4

Daphe, Collina ......................... 37

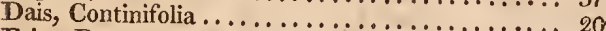

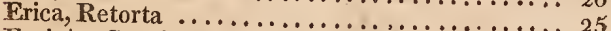

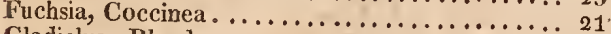

Gladiolus, Blandus . $\ldots \ldots \ldots \ldots \ldots \ldots . \ldots \ldots$

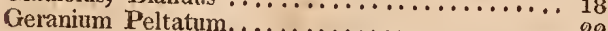

Goteria, Rigens. . . . . . . . . . . . . . . . . . .

Geissorphiza, Obtusata .................

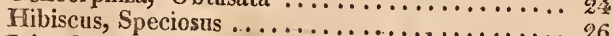

Tria, Crocata $\ldots \ldots \ldots \ldots \ldots \ldots \ldots \ldots . \ldots \ldots$

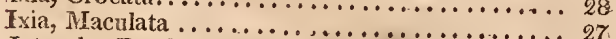

Jatropla, Pandumefolia $\ldots \ldots \ldots \ldots \ldots \ldots . . \ldots \ldots$

Lobelia, Coronopifolia ... . . . . . . . . . . . . 43

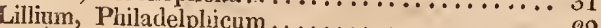

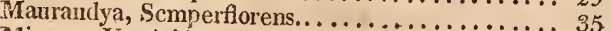

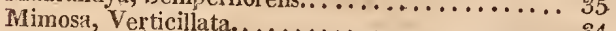

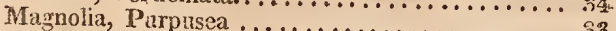

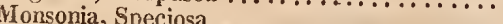

Manraea, Spiralis . . . . . . . . . . . . . . . . . 36

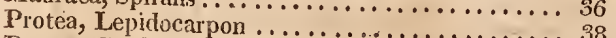

Protea, Cordifolia. . . . . . . . . . . . . . . 38

Phiox, Stronfer

Purica, Na

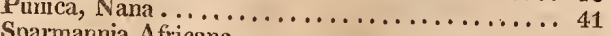

Sparmannia Africana . . . . . . . . . . . . . . . . 48

Siene, Ornata $\ldots \ldots \ldots \ldots \ldots \ldots \ldots \ldots \ldots \ldots \ldots \ldots \ldots . \ldots \ldots$

Saphora Australis....................... $9 . \ldots$

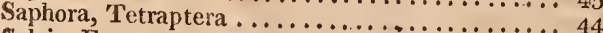

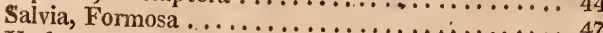

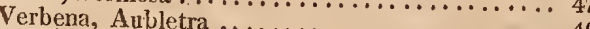

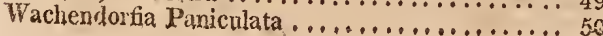

